\title{
UTILIZAÇÃO DA LEVEDURA DESIDRATADA COMO FONTE DE PROTEÍNA PARA SUÍNOS EM CRESCIMENTO E TERMINAÇÃO
}

\author{
JOSÉ APARECIDO MOREIRA \\ Biólogo \\ Orientador: Prof. Dr. VALDOMIRO SHIGUERU MIYADA \\ Dissertação apresentada à Escola Superior de \\ Agricultura "Luiz de Queiroz", Universidade de \\ São Paulo, para obtenção do título de Mestre \\ em Agronomia, Área de Concentração: Ciência \\ Animal e Pastagens.
}

PIRACICABA

Estado de São Paulo - Brasil

Abril - 1998 
Errata

Na página ix, ao invés de se ler "Página $52,53,54,55,56,57,58$ e 59", leia - se "Página 51, 52,53, 54, 55, 56, 57 e 58".

Na página xil e xiii, ao invés de se ler "weight and percentage of ham", leia - se "percentage of ham". No parágrafo onde está escrito "during growing (ADG = 1.0205 $\left.-.0124 X ; R^{2}=.69\right)$, finishing $\left(A D G=1.1036-.0182 X ; R^{2}=.68\right.$ ) and overall period $\left(A D G=1.0619-.0156 X ; R^{2}=.76\right)$ ", leia - se "during growing (ADG = 1.008314 $\left..003556 X ; R^{2}=.70\right)$, finishing $\left(A D G=1.085638-.005197 X ; R^{2}=.68\right)$ and overall period $\left(A D G=1.04352-.004067 X ; R^{2}=.54\right)$ e no parágrafo onde está escrito "during growing $\left(F / G=2.2707+.0489 X ; R^{2}=.89\right)$ and overall period $(F / G=2.5827+$ $\left..0326 X: R^{2}=.60\right)$ ", leia - se "during growing $\left(F / G=2.323429+.013780 X ; R^{2}=.89\right)$ and overall period $\left(F / G=2.614667+.009029 X ; R^{2}=.48\right)$ ".

Na página 3, ao invés de se ler "(Lima et al., 1983)", leia - se "(Lima et al., 1987)".

Na página 6 , onde está escrito "centro de treinamento copersucar (CTC)", leia - se "Centro de Tecnologia Copersucar (CTC)".

Na Tabela 1. ao invés de se ler "ED kcal/kg 29,08, 31,93,33,56,31,71,34,48 e 31,57" leia - se "ED (kcal/kg) 2908, 3193, 3356, 3171, 3448 e 3157".

$\mathrm{Na}$ página 13, ao invés de se ler "Foi estudado níveis de até $45 \%$ de $\mathrm{PB}$ da levedura de recuperação, em substituição ao farelo de soja", leia - se, "Foram estudados níveis de até $45 \%$ da $\mathrm{PB}$ da ração usando a levedura de recuperação, em substituição a proteína do milho e farelo de soja".

Nas páginas xi e 31, ao invés de se ler "crescimento (GDP = 1,0205- 0,0124X: $R^{2}$ $=0,69$ ), terminação (GDP $\left.=1,1036-0,0182 X ; R^{2}=0,68\right)$ e período total (GDP 1,0619 - 0,0156X; $\left.R^{2}=0,76\right)$ ", leia - se "crescimento $\left(G D P=1,008314-0,003556 X ; R^{2}=\right.$ $0,70)$, terminação (GDP $\left.=1,085638-0,005197 X ; R^{2}=0,68\right)$ e período total $(G D P=$ $\left.1,04352-0,004067 X_{i} R^{2}=0,54\right)$ ". Nas páginas $x i$ e 37 , onde está escrito " crescimento $\left(C A=2,2707+0,0489 X ; R^{2}=0,89\right)$ e período total $(C A=2,5827+$ $\left.0,0326 X ; R^{2}=0,60\right)$ ", leia - se "crescimento $\left(C A=2,323429+0,013780 X ; R^{2}=0,89\right)$ e período total $\left(C A=2,614667+0,009029 X ; R^{2}=0,48\right)$ ".

$\mathrm{Na}$ página 35 considerar correto este gráfico para o período total.

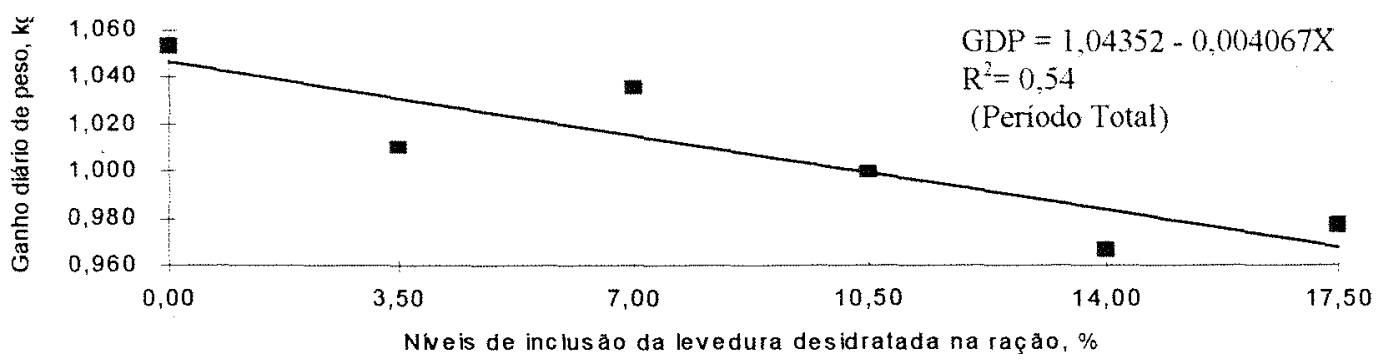

Nas páginas 54 a 58 ao invés de se ler "RCG,PP e RP", leia - se "RG/C, PsP e PP" e nas páginas 57 e 58 ao invés de se ler "Tabela A6 e Tabela A7", leia - se "Tabela A7 e Tabela A8". 
Dados Internacionais de Catalogaçāo na Publicaçāo (CIP) DIVISÃo DE BIBLIOTECA E DOCUMENTAÇĀO - Campus "Luiz de Queiroz"/USP

Moreira, José Aparecido

Utilização da levedura desidratada como fonte de proteina para suínos em crescimento e terminaçăo / José Aparecido Moreira. - Piracicaba, 1998.

58 p. : il

Dissertação (mestrado) - Escola Superior de Agricultura Luiz de Queiroz, 1998.

Bibliografia.

1. Abate 2. Alimentação animal 3. Carcaça 4. Levedura 5. Proteina 6. Suino I. Título

CDD 636.4 
iii

Ofereça

A Deus pai tado paderasa. que

sempre esteve presente em men coração.

Aos mens queridos pais. Afansa Julia

Moreira (in memarian) e Maria Aparecida

Moraes (in memorian), que sempre estiveram

comiga

Dedica

It minha querida espasa. Vania Celeste Moreira, pelo seu carinho, paciência e incentivas; dedica também à nossa

filhinha Amanda. que amamos meita! 


\section{AGRADECIMENTOS}

Ao Prof. Dr. Valdomiro Shigueru Miyada, verdadeiro mestre e orientador, ao qual, todas as palavras são poucas para expressar a minha eterna gratidão, por tudo que fez para minha formação;

Ao CAPES - Fundação Coordenação de Aperfeiçoamento de Pessoal de Nivel Superior, pela concessão da bolsa de estudos, que contribuiu para tornar o meu sonho realidade;

Ao professor Dr. Irineu Umberto Packer, pelas sugestōes referentes a análise estatística;

A todos os professores do curso, pelos ensinamentos, dedicação e amizade;

À Supre Mais, representada pelo diretor, Engenheiro Agrônomo Eduardo Afonso Frandi Butolo, pela doação da levedura e apoio financeiro, no desenvolvimento do experimento;

A Zootecnista Márcia Cristina lafigliola, estagiária do setor de Suinocultura, por todo apoio que deu durante a realização do experimento e por sua amizade;

Aos meus amigos e companheiros do curso, Marcos, Alcester, Mônica e Isabel, por todo apoio que me deram, durante o curso e principalmente durante o desenvolvimento do experimento, e a todos os amigos da pós-graduação, pela amizade e convivência;

Deixo também, meus mais sinceros agradecimentos aos senhores Pires, Ventura, Geraldo, Benedito e José Galvão, pelo carinho e amizade que nos ofereceram, durante a condução do experimento; 


\section{SUMÁRIO}

Página

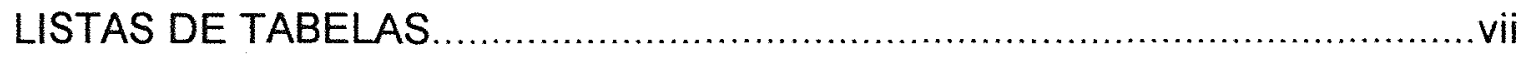

LISTAS DE FIGURAS.............................................................................ii

LISTAS DE TABELAS DO APÊNDICE .................................................... ix

RESUMO

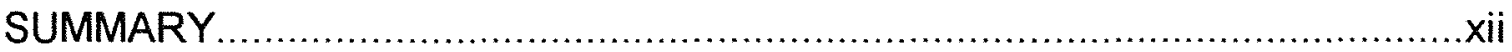

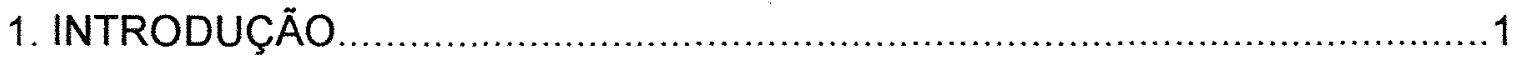

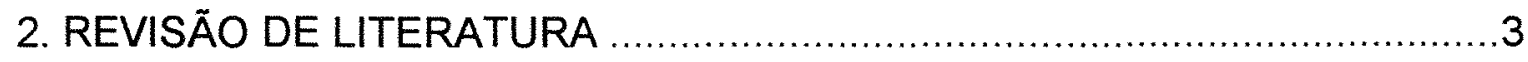

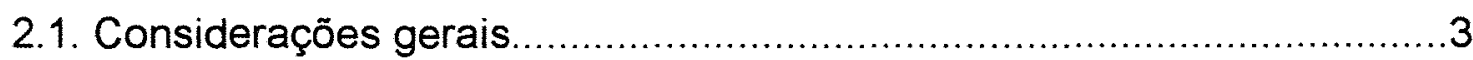

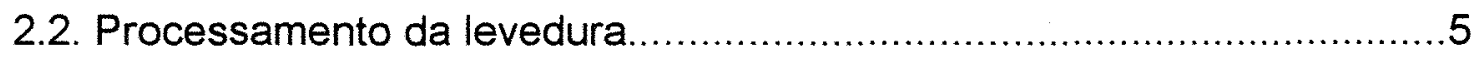

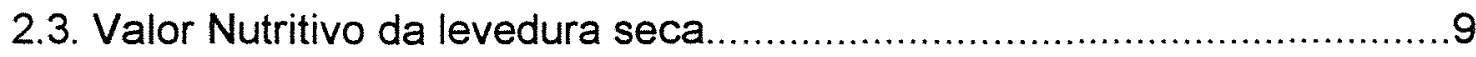

2.4. Utilização da levedura desidratada na alimentação de

suínos.

2.5. Efeito da levedura desidratada sobre o desempenho e qualidade de carcaça de suínos

3. MATERIAL E MÉTODOS.

3.1. Planejamento, condução e coleta dos dados

experimentais

3.2. O experimento e seu objetivo. 
6. CONCLUSÖES.

REFERÊNCIAS BIBLIOGRÁFICAS

APÊNDICE. 


\section{LISTA DE TABELAS}

Página

1 Composição da levedura seca e do farelo de soja. 12

2 Distribuição dos animais por tratamento nos blocos, no final do período experimental

3 Composição química e em aminoácidos da levedura desidratada. 21

4 Composição percentual das rações de crescimento. 22

5 Composição percentual das rações de terminação.

6 Médias de desempenho dos suínos na fase de crescimento 32

7 Médias de desempenho dos suínos na fase de terminação. 33

8 Médias de desempenho dos suínos no período total. 34

9 Características de carcaça. 


\section{LISTAS DE FIGURAS}

Página

1 Técnica para melhorar o teor protéico da levedura desidratada

2 Comprimento de carcaça.

3 Medidas de espessura de toucinho na primeira e última vértebras torácicas. .26

4 Medidas de espessura de toucinho entre a penúltima e última vértebras lombares e da área de olho de lombo. .27

5 Separação do pernil 28

6 Pesagem do pernil. .29

7 Efeito dos níveis de inclusão da levedura desidratada na ração sobre ganho diário de peso dos suínos nas fases de crescimento, terminação e período total. 35

8 Efeito dos níveis de inclusão da levedura desidratada na ração sobre a conversão alimentar dos suínos nas fase de crescimento, e período total. 


\section{LISTAS DE TABELAS DO APÊNDICE}

Página

A1 Desempenho de suínos na fase crescimento.

A2 Desempenho de suínos na fase de terminação.

53

A3 Desempenho de suínos no período total .54

A4 Dados originais da avaliação de carcaça do bloco 1 .55

A5 Dados originais da avaliação de carcaça do bloco 2 .56

A6 Dados originais da avaliação de carcaça do bloco 3 .57

A7 Dados originais da avaliação de carcaça do bloco 4 .58

A8 Dados originais da avaliação de carcaça do bloco 5 59 


\title{
UTILIZAÇÃO DA LEVEDURA DESIDRATADA COMO FONTE DE PROTEÍNA PARA SUÍNOS EM CRESCIMENTO E TERMINAÇÃO
}

\author{
Autor: JOSÉ APARECIDO MOREIRA \\ Orientador: Prof. Dr. VALDOMIRO SHIGUERU MIYADA
}

\section{RESUMO}

O presente estudo foi conduzido para avaliar o efeito da incorporação de niveis crescentes da levedura desidratada $(0,0,3,5,7,0,10,5$, 14,0 e $17,5 \%$ ), processada pelo método "spray dry", sobre a performance e características de carcaça de suínos em crescimento e terminação. Foram utilizados 78 leitões mestiços, sendo 36 machos castrados e 42 fêmeas, distribuidos num delineamento em blocos casualizados, de acordo com sexo, peso e grupo genético. As rações experimentais isoprotéicas (17,5 e 15,5\% PB) e isocalóricas (3251 e $3274 \mathrm{kcal}$ de energia digestivel) e a água, foram oferecidas 'a vontade aos animais durante o período experimental. Os animais e as rações foram pesados a cada 14 dias, para se obterem os dados de consumo diário de ração (CDR), ganho diário de peso (GDP) e conversão alimentar (CA). No final do experimento, os animais foram abatidos, para avaliar os seguintes parâmetros: rendimento e comprimento de carcaça, percentagem de pernil, espessura de toucinho, área do olho de lombo e relação gordura/carne. Os níveis da levedura desidratada não afetaram o CDR, mas foi observado um efeito linear negativo sobre o GDP, nos períodos 
de crescimento $\left(G D P=1,0205-0,0124 X ; R^{2}=0,69\right)$, terminação (GDP = $\left.1,1036-0,0182 X ; R^{2}=0,68\right)$ e período total (GDP $=1,0619-0,0156 X ; R^{2}=$ $0,76)$, assim como para $C A$, nas fases de crescimento $(C A=2,2707+$ $\left.0,0489 X ; R^{2}=0,89\right)$ e periodo total $\left(C A=2,5827+0,0326 X ; R^{2}=0,60\right)$ As caracteristicas de carcaça não foram afetadas pelos niveis crescentes da levedura. Embora tenha havido efeito linear depressivo no GDP e na CA com a incorporação da levedura na ração, há evidência de que o nível de $7 \%$ pode proporcionar performance e características de carcaça semelhantes àquelas obtidas com dietas baseadas em milho e farelo de soja. 


\title{
UTILIZATION OF DRIED YEAST AS A PROTEIN SOURCE FOR GROWING - FINISHING SWINE
}

\author{
Author: JOSÉ APARECIDO MOREIRA \\ Adviser: DR. VALDOMIRO SHIGUERU MIYADA
}

\section{SUMMARY}

The present study was carried out to evaluate the effect of increasing levels of dried yeast ("spray dry" method) on performance and carcass trais of growing-finishing swine. Seventy-eight crossbred pigs, 36 barrows and 42 gilts, were distributed to six treatments based on sex, live weight and genetic group. The treatments were diets containing: 0.0 (diet based on corn and soybean meal), 3.5, 7.0, 10.5, 14.0, and $17.5 \%$ of dried yeast. The experimental diets were isonitrogenous and isocaloric for each period. During the experimental period, diets and water were given "ad libitum" and the pigs were weighed every 14-days period, to obtain the daily feed intake (DFI), averange daily gain (ADG), and feed/gain ratio (F/G). At the end of the experimental period, the animals were slaughtered to evaluate the fallowing traits: dressing percentagem, carcass length, weight and percentage of ham, backfat thickness, loin eye area.and fat/meat ratio. The levels of dried yeast did not affect the $D F I$, but had a depressive effect on $A D G$, during growing $\left(A D G=1.0205-.0124 X ; R^{2}=.69\right)$, finishing $(A D G=1.1036-.0182 X$; $\left.R^{2}=.68\right)$ and overall period $\left(A D G=1.0619-.0156 X ; R^{2}=.76\right)$. In addition, the dried yeast also showed a negative linear effect on $F / G$, during growing 
$\left(F / G=2.2707+.0489 X ; R^{2}=.89\right)$ and overall period $(F / G=2.5827+.0326 X ;$ $\mathrm{R}^{2}=.60$ ). The carcass traits were not affected by the increasing dietary level of the dried yeast. The results of this experiment indicated that dried yeast (Saccharomyces sp.) processed by "spray dry" method can be used as a source of protein for growing and finishing pigs, up to the level of $17.5 \%$. However, pigs fed the diet containing $7.0 \%$ of dried yeast showed similar performance to those of control diet. 


\section{INTRODUÇÃO}

A falta de alimentos é um problema que tem afetado seria e permanentemente a população humana, e vem se agravando dia a dia no mundo todo, especialmente em certas áreas do Brasil.

$\mathrm{Na}$ tentativa de solucionar a carência de alimentos, especialmente de proteínas, vários processos não convencionais têm sido desenvolvidos. Alguns deles permitem a obtenção de proteínas, a partir de microorganismos, denominadas de proteínas unicelulares ou bioproteinas que podem ser utilizadas na nutrição humana e em formulação de ração para animais.

Dentre os alimentos não convencionais utilizados na alimentação animal, a levedura tem demonstrado ser um alimento de excelente qualidade. No entanto, os resultados de pesquisas não são totalmente concordantes, possivelmente devido às variações na linhagem de levedura, composição, processamento etc.

Diversos pesquisadores já trabalharam com levedura nas fases de recria, crescimento, terminação e reprodução. Contudo, o desenvolvimento desse trabalho se justifica pelo surgimento do método de processamento "Spray Dry", que traz uma série de vantagens quando comparado com o sistema convencional, resultando em um produto de qualidade superior, conforme descrito na literatura.

Por outro lado, grandes investimentos foram feitos em material genético, sendo que na atualidade se encontra no mercado, animais com um 
potencial genético extraordinário para o ganho de peso, produzindo carcaça de excelente qualidade.

O objetivo do presente estudo, foi o de avaliar o melhor nivel de inclusão da levedura desidratada, processada pelo método "spray dry", como fonte de proteína para suínos em crescimento e terminação. 


\section{REVISÃO DE LITERATURA}

\subsection{Considerações gerais}

A organização das Nações Unidas para agricultura e alimentação (FAO) estima para o ano 2000 um total de 510 a 530 milhões de pessoas desnutridas no mundo (Gessulli, 1991). Isto mostra a importância em se produzir alimentos com preços compativeis com o poder aquisitivo das populações mais carentes.

A população infantil no Brasil está estimada em cerca de 25 milhões, sendo que uma parcela considerável desse contingente é acometida de desnutrição. A taxa de mortalidade infantil é altíssima e a maioria das crianças que sobrevivem tem seu potencial físico e intelectual comprometido (Monteiro et al., 1991).

São consumidos pelos seres humanos aproximadamente 82 milhões de toneladas de proteínas anualmente, sendo 40 milhões obtidas dos cereais e o restante de outras fontes como: carne, leite, ovos e outros. A carne constitui uma fonte de proteína de excelente qualidade para os seres humanos, pois possui um balanço de aminoácidos extraordinário (Bhattacharjee, 1970).

Em uma suinocultura, a alimentação representa cerca de $70 \%$ dos custos variáveis na produção de suinos (Lima et al., 1983). Portanto a utilização das fontes alternativas de alimentos para suínos é extremamente importante, tendo como objetivo reduzir o custo da ração. 
Uma fonte alternativa, que vem chamando a atenção de técnicos e criadores de suínos são os alimentos não-convencionais, que são obtidos a partir de microorganismos (algas, fungos, leveduras, liquens e bactérias) (Bhattacharjee, 1970).

No Brasil a levedura de destilarias de álcool de cana de açúcar (Saccharomyces cerevisiae), vem sendo estudada como fonte alternativa de proteína para suínos, desde 1977, periodo em que ficou caracterizado, este alimento, como mais uma fonte de proteina para suínos, nas fases de recria, crescimento, terminação e reprodução (Miyada \& Lavorenti, 1979; Lima, 1983; Moreira, 1984; Berto, 1985; Miyada, 1987; Kronka et al., 1987; Nunes, 1988; Miyada et al., 1992, 1997; Landell Filho et al., 1993a, 1994; Citroni, 1995; Moreira et al., 1996, 1997).

$\mathrm{Na}$ nutrição humana, um dos inconvenientes da utilização da levedura como alimento é o seu alto teor de ácidos nucléicos, cerca de $15 \%$ do nitrogênio total é devido aos mesmos (Harper, 1982).

As bases pirimídicas são metabolizadas principalmente no fígado, resultando na produção de uma série de produtos finais, altamente solúveis, como beta-alanina e o ácido beta-aminoisobutírico (Harper,1982).

As bases púricas, no entanto, são metabolizadas a ácido úrico que se acumulam no sangue dos seres humanos e provocam um doença chamada "gota", as articulações tornam-se inflamadas, dolorosas e artríticas, devido a uma deposição anormal dos cristais de urato de sódio.

Os rins também são afetados, pois os excessos de urato de sódio também são depositados nos túbulos renais (Stryer, 1992; Lehninger, 1995).

Com os suínos, estas anormalidades não ocorrem, pois estes animais são capazes de metabolizar as bases púricas em ácido úrico e este em alantoina, que é excretada na urina (Lenhinger, 1995).

Sendo assim, as leveduras podem substituir na íntegra o farelo de soja, pois os componentes sangüíneos (hematócrito e hemoglobina) e séricos 
(uréia, ácido úrico, proteína total, albumina, globulina e colesterol) analisados por diversos pesquisadores (Berto, 1985; Miyada, 1987; Landell Filho et al., 1993b) permaneceram dentro dos valores normais para suínos em recria, crescimento e terminação.

Existem várias espécies de leveduras (Candida utilis, Candida lipolytica, Rhodotorula gracis, Saccharomyces carlsbergensis, Saccharomyces cerevisae, etc), que são obtidas a partir de diversos substratos (melaços, hidrocarbonetos, cereais, etc) onde são cultivadas (Citroni, 1995).

O gênero Saccharomyces engloba leveduras esféricas, elipsoidais $e$, ocasionalmente, cilindricas, que se reproduzem vegetativamente por brotamento multilateral (Noble, 1981).

Para a utilização da levedura na nutrição animal, é necessário que elas estejam mortas e desidratadas, evitando assim, qualquer efeito indesejável aos animais (Miyada, 1987).

\subsection{Processamento da levedura}

A levedura de recuperação, utilizada na nutrição animal, são excedentes gerados nos processos fermentativos, das destilarias de álcool da cana-de-açúcar, sangrados e posteriormente secados.

Segundo Rheinboldt et al. (1987), o processo convencional de secagem é composto de etapas de recuperação do etanol, termólise executadas no leite de levedura e secagem onde se utiliza tambor rotativo.

Este tipo de processamento, apresenta diversas dificuldades técnica - operacional como: pequena capacidade individual de produção, manutenção intensiva, alto consumo energético e qualidade do produto final não muito adequada, apresentando sinais de desnaturação (queima) e umidade não muito uniforme (Rheinboldt et al., 1987). 
Devido ao sucesso da levedura como alimento, vários tipos de secadores foram desenvolvidos, dentre eles o turbo dry e spray dry (Pinotti, 1997).

O secador de levedura, denominado turbo dry foi desenvolvido por pesquisadores da copersucar, e vem demonstrando algumas vantagens, quando comparados com o secador de tambor, como maior capacidade de produção (10 ton/dia), substituindo assim, muitos módulos dos secadores de tambor, secando com muito mais regularidade; uma outra vantagem é a utilização de uma menor mão de obra (Rheiboldt et al., 1987). Mas apesar destas vantagens, este tipo de secador, não vem obtendo sucesso, em função do seu alto custo de implantação (Pinotti, 1997).

Os secadores spray dry, hoje muito utilizados pelos grandes produtores da levedura desidratada, vem demonstrando algumas vantagens em comparação com os secadores de tambor, quanto ao custo de produção e a qualidade do produto obtido (Ghiraldini \& Rossell, 1997).

Foram também desenvolvidas algumas técnicas, visando melhorar a qualidade da levedura, como o processo de estarvação (Figura 1), utilizado para aumentar o valor protéico deste alimento (Ghiraldini \& Rossell, 1997). Neste processo, as leveduras consomem as substâncias de reservas (carboidratos) acumuladas nas células, transformando-as em álcool, e como conseqüências, obtem-se na massa resultante, um aumento do teor de proteínas .

Em estudos conduzidos, pelo centro de treinamento copersucar (CTC), foi constatado aumentos médios de $20 \%$, no teor de proteínas para o leite de levedura, que possuia teores iniciais ao redor de $30 \%$. Este processo de estarvação, provoca uma perda da massa da levedura seca em torno de $20 \%$, porém os ganhos em teor protéico e a recuperação do etanol, mostraram 


\section{LEITE DE LEVEDURA (IN NATURA)}

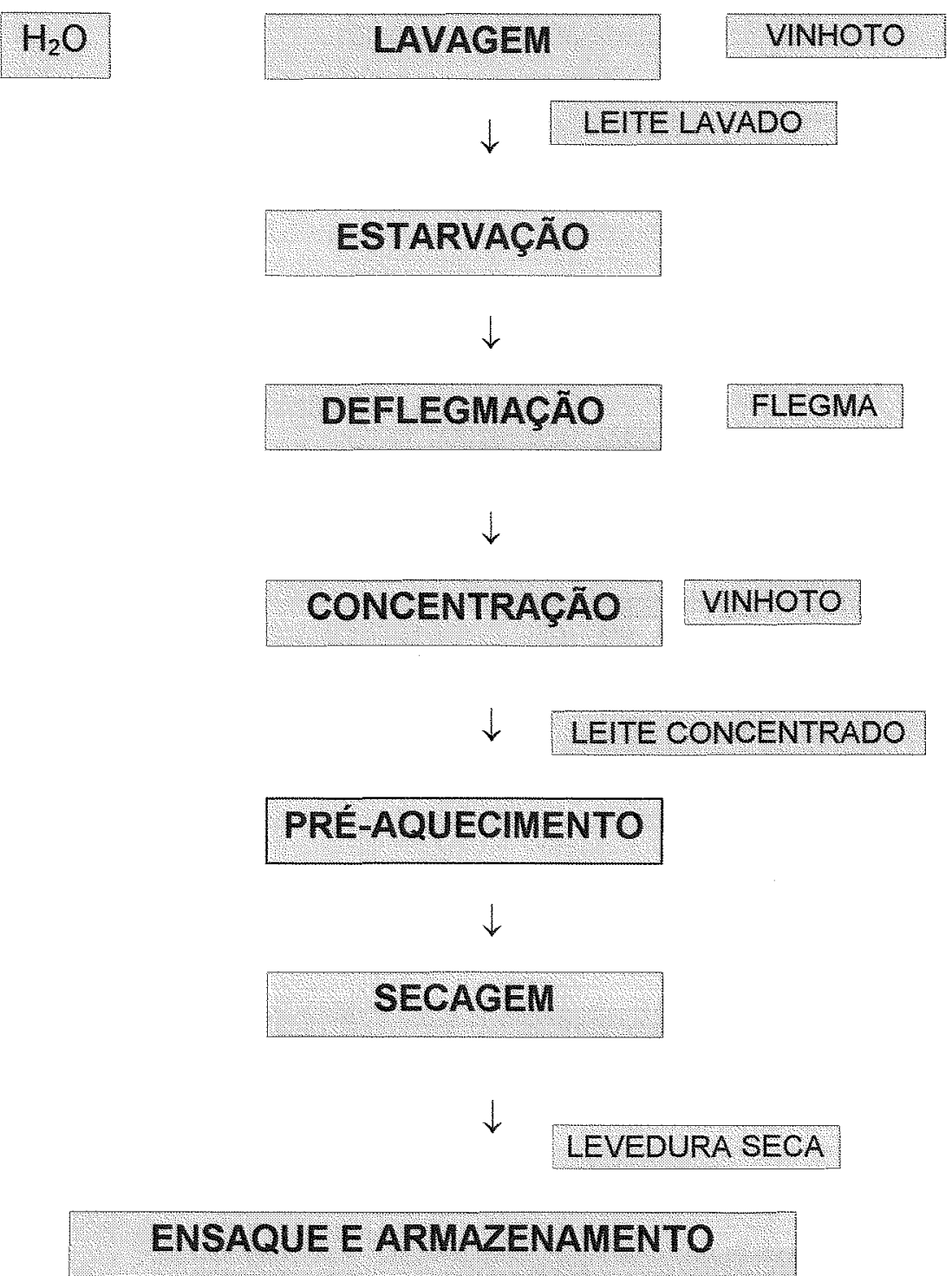

Figura 1. Técnica para melhorar o teor protéico da levedura desidratada. 
que esse processamento é muito favorável (Ghiraldini \& Rossell, 1997).

O sistema de produção da levedura seca, a partir do leite de levedura, compreende uma seqüencia de processos físicos e químicos que estão representados na Figura 1.

Este processo se inicia com a lavagem por centrifugação do leite da levedura, operação que tem por objetivo, remover impurezas e recuperar parte do etanol perdido.

O leite de levedura recuperado é submetido a um processo de estarvação. Durante esta etapa, as leveduras consomem as substâncias de reserva (carboidratos) acumuladas nas células, transformando-as em álcool.

Este material, resultante da operação anterior é submetido a uma deflegmação, em uma coluna de destilação de pratos perfurados. Durante a destilação, o etanol é recuperado no topo da coluna; sendo este processo extremamente importante, pois perde-se, aproximadamente 1 litro de etanol, por $3 \mathrm{~kg}$ de levedura seca produzida, caso não se efetue a sua recuperação (Rheinboldt et al., 1987).

O leite da levedura é termolisado, para que ocorra uma desativação celular, necessária para a sua utilização na composição de rações. A permanência do leite da levedura por aproximadamente 15 minutos a $105^{\circ} \mathrm{C}$, no fundo da coluna deflegmadora, assegura uma termólise eficiente (Ghiraldini \& Rossell, 1997).

Para reduzir os custos com a secagem do leite da levedura é necessário, que se realize a retirada de água por desaguamento mecânico, permitindo um maior desempenho e eficiência dos secadores (Rheinboldt et al., 1987).

A levedura pré-concentrada é submetida a um pré-aquecimento em trocadores de calor e é imediatamente bombeada para as unidades de secagem. Dos diversos tipos de secadores disponiveis no mercado, para a secagem da levedura, apenas os secadores de tambor, spray dry e turbo dry 
tem apresentado sucesso comercial. Dentre esses secadores, o secador turbo dry tem sido pouco difundido em função do seu elevado custo de implantação (Ghiraldini \& Rossell, 1997), e o secador spray dry vem sendo muito utilizado pelos grandes produtores da levedura.

\subsection{Valor Nutritivo da Levedura Seca}

Encontra-se na literatura, leveduras com composições em proteínas, aminoácidos e vitaminas, completamente distintas. Estas diferenças nas composições, ocorrem em função de uma série de fatores, tais como, o substrato, as linhagens das leveduras $e$ as condições de fermentação (Desmont, 1968; Ghiraldini \& Rossel, 1997); um outro fator que pode contribuir para a qualidade da levedura seca é o processamento (Rheinboldt et al., 1987). A composição química e os valores energéticos da levedura de recuperação, em comparação com o farelo de soja, podem ser observados na Tabela 1

As células das leveduras apresentam um elevado teor de proteina bruta, comparável aos encontrados nos suplementos protéicos de origem vegetal e animal.

Normalmente o valor protéico da levedura é determinado pelo método Kjeldahl, onde determina-se o nitrogênio total da amostra e multiplicase por 6,25 (Maynard \& Lossli, 1966). Neste processo, considera-se que todo o nitrogênio seja protéico, mas principalmente, no caso dos microorganismos, isso não ocorre, pois cerca de 10 a $35 \%$ do nitrogênio celular, não são protéicos, sendo originários das bases púricas e pirimídicas dos ácidos nucléicos e em menor quantidade em outros compostos (Miyada, 1987).

A levedura de recuperação (Saccharomyces cerevisiae), muito estudada aqui no Brasil, no período compreendido entre 1977 e 1997, 
apresentaram um valor protéico que variou entre 26,89 a 33,01 de PB (Miyada \& Lavorenti, 1979; Fialho et al., 1983, 1985; Lima et al., 1987; Embrapa, 1991; Miyada et al., 1992, 1997; Landell Filho et al., 1993a, 1994; Citroni, 1995.

A variação da composição química, entre os vários tipos de leveduras, resultam em diferentes valores nutritivos.

Analisando a Tabela 1, pode se generalizar que as leveduras, em termos de teor protéico, são semelhantes ao farelo de soja, principalmente se for considerado os teores dos quatros aminoácidos limitantes para suínos, ou seja, lisina, triptofano, treonina e metionina. O conteúdo de lisina apresentou média de 1,96 comparado com 2,65 do farelo de soja, mas valores de até 6,6 de lisina foram constatados por Cozzolino (1982). No entanto alguns pesquisadores afirmam que as leveduras são relativamente pobres, em aminoácidos sulfurados (Wasserman, 1961; Desmonts, 1968; Hanssen, 1981), constituindo o fator limitante das leveduras, como fonte de proteínas para suínos ou para outros monogástricos. Mas de uma forma geral, quando as leveduras são suplementadas com metionina, elas se tornam até superiores ao farelo de soja (Tegbe \& Zimmerman, 1977).

O valor nutritivo de um alimento está condicionado com seu balanço em nutrientes e com a sua disponibilidade biológica; portanto, além da análise bromatológica são necessários os ensaios biológicos, pois estes completam a avaliação (Berto, 1985). Desta forma os animais alimentados com a levedura, podem apresentar baixo desempenho, associados com toxidade, digestibilidade, ou impalatabilidade e não estar associado com o desbalanço de aminoácidos ou deficiência nutricional (Asplund \& Pfander, 1973).

Cerca de $35 \%$ do total de aminoácidos das leveduras podem estar associados a parede celular (Cunningham et al., 1975), que é constituída por proteina, glicano (30 a 34\%), manano (30\%) e concentrações de lipídios que variam de 8,5 a 13,5\% (Pelczar, 1981); esta parede celular pode comprometer 
a utilização dos aminoácidos, contidos no citoplasma dessas células (Vananuvat, 1977), quando não processadas adequadamente.

O processamento é extremamente importante, pois provoca a ruptura da parede celular, liberando o conteúdo intracelular (Miyada, 1987). 
Tabela 1. Composição da levedura seca e do farelo de soja.

\begin{tabular}{|c|c|c|c|c|c|c|c|c|c|}
\hline & 1 & 2 & 3 & 4 & 5 & 6 & 7 & 8 & 9 \\
\hline MS, $\%$ & 90,70 & 93,90 & 86,00 & 92,34 & 90,13 & 88,96 & - & 88,22 & 90,34 \\
\hline $\mathrm{PB}, \%$ & 30,77 & 30,62 & 31,82 & 29,17 & 31,39 & 33,01 & 29,23 & 44,84 & 30,77 \\
\hline ED kcal/kg & - & 29,08 & 31,93 & - & 33,56 & 31,71 & - & 34,48 & 31,57 \\
\hline Lisina, \% & 1,87 & 1,75 & 1,75 & 1,88 & 2,07 & 2,17 & 2,24 & 2,65 & 1,96 \\
\hline Triptof., \% & - & 0,56 & 0,42 & 0,56 & 0,52 & 0,39 & - & 0,74 & 0,49 \\
\hline Metion., \% & 1,27 & 0,47 & 0,47 & 0,40 & 0,43 & 0,52 & 0,51 & 0,46 & 0,58 \\
\hline Treonina, \% & 1,57 & 1,37 & 1,37 & 1,37 & 1,58 & 1,75 & 1,64 & 1,60 & 1,52 \\
\hline Histidina, \% & 0,47 & - & - & 0,48 & 0,69 & - & 0,60 & 1,27 & 0,56 \\
\hline Fenilal., \% & 1,06 & 1,27 & 1,27 & 1,13 & 1,18 & 1,40 & 1,27 & 1,86 & 1,23 \\
\hline Arginina, $\%$ & 0,98 & 1,35 & 1,35 & 1,24 & 1,36 & 1,16 & 1,37 & 3,27 & 1,26 \\
\hline Leucina, \% & 2,02 & 2,41 & 2,41 & 2,07 & 2,17 & 2,46 & 2,23 & 3,17 & 2,25 \\
\hline \multicolumn{10}{|c|}{ Saccharomyces cerevisiae recuperada do vinho (Miyada \& Lavorenti, 1979). } \\
\hline \multicolumn{10}{|c|}{${ }^{2}$ Saccharomyces cerevisiae recuperada do vinho (Fialho et al., 1983). } \\
\hline \multicolumn{10}{|c|}{${ }^{3}$ Saccharomyces cerevisiae recuperada do vinho escuro (Fialho et al., 1985). } \\
\hline \multicolumn{10}{|c|}{${ }^{4}$ Saccharomyces cerevisiae recuperada do vinho (Lima et al., 1987). } \\
\hline \multicolumn{10}{|c|}{${ }^{5}$ Saccharomyces cerevisiae recuperada do vinho (Embrapa, 1991). } \\
\hline \multicolumn{10}{|c|}{${ }^{6}$ Saccharomyces cerevisiae recuperada do vinhaça (Landell Filho et al., 1993 e 1994). } \\
\hline \multicolumn{10}{|c|}{${ }^{7}$ Saccharomyces cerevisiae recuperada do vinho (Citroni, 1995). } \\
\hline \multicolumn{10}{|c|}{${ }^{8}$ Farelo de Soja - $45 \%$ de P.B. (Embrapa, 1991). } \\
\hline${ }^{9}$ Média do $1-$ & & & & & & & & & \\
\hline
\end{tabular}




\subsection{Utilização da levedura desidratada na alimentação de suinos}

São vários os tipos de leveduras, relatados na literatura, que podem ser utilizados como fonte protéicas para os suínos. No entanto, para as condições brasileiras a levedura de recuperação (Saccharomyces $s p$.), obtida em destilarias de álcool de cana-de-açucar, é a que tem um significado maior.

A ESALQ/USP através do Departamento de Zootecnia, vem estudando a levedura como fonte de proteína para suinos, desde de 1977 , neste período, ficou caracterizado este alimento como uma excelente fonte de proteína para suinos em recria, crescimento, terminação e reprodução (Miyada \& Lavorenti, 1979; Lima, 1983; Moreira, 1984; Berto, 1985; Miyada, 1987; Miyada et al., 1992, 1997; Citroni, 1995).

Pesquisadores de outras universidades, também estudaram a levedura, como fonte de proteína para suínos (Kronka et al., 1987; Nunes, 1988; Landell Filho et al., 1993a, 1994; Moreira et al., 1996, 1997; Zanutto et al., 1997).

Este subproduto pode constituir em até $21 \%$ a ração de suínos em recria, crescimento, terminação, gestação e lactação (Miyada \& Lavorenti, 1979; Lima, 1983; Menten et al.,1984; Moreira, 1984; Berto, 1985). Contudo os melhores níveis de utilização, estão entre 8 e 12\% (Miyada, 1987; Nunes, 1988; Miyada et al. 1992; Landell Filho et al., 1993a).

Foi estudado níveis de até $45 \%$ de PB da levedura de recuperação, em substituição ao farelo de soja, para leitões em recria (Berto, 1985), onde se observou aumento no consumo de ração e piora na conversão alimentar, com o aumento dos níveis da levedura. Com relação à levedura de centrifugação da vinhaça, niveis de até $100 \%$ da proteína bruta da levedura em substituição ao farelo de soja, foi estudado, em rações para suínos em crescimento e terminação (Landell Filho et al., 1993a); e ficou constatado que os melhores niveis de inclusão na ração seria de 12,6 e $8,6 \%$ respectivamente. 


\subsection{Efeito da levedura desidratada sobre o desempenho e qualidade de carcaça de suínos.}

Uma série de pesquisas foram feitas, para avaliar o potencial da levedura de recuperação como fonte de proteína, para suínos, nas diversas fases do seu ciclo produtivo.

A levedura de recuperação quando processadas, possuem grânulometria menor ou igual a 0,5mm (Ghiraldini \& Rossell, 1997), por isso, quando utilizada em niveis elevado nas rações, pode diminuir o consumo, em função de uma maior pulverulência e consistência pegajosa, na boca dos animais (Tegbe \& Zimmerman, 1977).

Foram estudados suínos na fase de recria, utilizando rações isoprotéicas contendo níveis crescentes da levedura (28 e 20\%) (Berto, 1985; Kronka et al.,1987), onde observaram aumento no consumo de ração (Berto, 1985), ao contrário de Tegbe \& Zimmerman (1977) que constataram diminuição no consumo; também foi observado piora linear na conversão alimentar (Berto, 1985); mas não foi detectado diferença no ganho de peso (Berto, 1985; Kronka et al., 1987, Moreira, et al.,1997).

Sendo as rações peletizadas, pode se utilizar até $20 \%$ deste subproduto para suínos na fase inicial, podendo até mesmo melhorar o seu valor nutritivo (Miyada et al., 1992,1997; Moreira et.al., 1997).

Um outro tipo de levedura estudado, para suínos em recria, foi a levedura de centrifugação da vinhaça (Landell Filho et al., 1994); utilizando niveis de 0 a $20 \%$, em rações farelada, estes autores observaram decréscimo no ganho de peso e piora na conversão alimentar.

Quanto aos suínos em crescimento e terminação, Miyada \& Lavorenti (1979) verificaram que não houve diferença no ganho diário de peso, mas o consumo de ração, a conversão alimentar e a percentagem de pernil aumentaram, enquanto a espessura de toucinho diminuiu linearmente com a 
adição de níveis crescentes de até $21 \%$ de levedura seca em rações isoprotéicas, à base de milho e farelo de soja; segundo os autores, isto ocorreu, possivelmente, devido a redução no conteúdo de energia e aumento no consumo de proteína e lisina, proporcionado pela inclusão da levedura na ração.

Mais tarde Moreira (1984), em um estudo utilizando rações isoprotéicas e isoenergéticas, não observou diferença no desempenho e características de carcaça em suínos alimentados com rações contendo níveis de 0 a $15 \%$ da levedura.

Outros experimentos também foram desenvolvidos no Brasil, com suínos nas fases de recria, crescimento e terminação, onde se chegou a conclusão que os melhores niveis de utilização, estão em torno de $10 \%$, pois níveis acima, provocaram redução no consumo de ração, no ganho de peso (Miyada et al., 1992; Landell Filho et al., 1993a, 1994 ), na área de olho de lombo e pioraram a conversão alimentar (Landell Filho et al., 1993a).

Fêmeas em gestação e lactação também foram estudadas (Lima, 1983), onde se utilizou niveis de 0 a $21 \%$ da levedura em quatro ciclos reprodutivos. Neste experimento foi observado, que não só o número dos leitões nascidos vivos, como o número de leitões vivos aos 21 dias e a desmama (35 dias), assim como o peso das leitegadas ao nascer, apresentaram uma tendência linear em aumentar, com os níveis crescentes da levedura. Segundo o autor, isto ocorreu provavelmente, devido a elevação da concentração em vitaminas do complexo $b$, ocasionadas pelos níveis crescentes da levedura.

Miyada (1987) estudou a levedura como fonte de vitaminas para suínos em recria, crescimento e terminação, e constatou que este subproduto pode participar das rações de suínos em crescimento e terminação a um nivel de $15 \%$, sem prejudicar a performance dos animais; embora com animais em 
recria, há indicação de que as rações necessitem ser suplementadas, com pelo menos, $50 \%$ das doses de premix recomendadas na prática. 


\section{MATERIAL E MÉTODOS}

\subsection{Planejamento, condução e coleta dos dados experimentais}

O presente estudo foi conduzido no Departamento de Zootecnia da Escola Superior de Agricultura "Luiz de Queiroz", Universidade de São Paulo, em Piracicaba, SP, no período de janeiro a abril de 1997, envolvendo um total de 78 animais mestiços.

A levedura que foi utilizada neste experimento é a levedura de recuperação, obtida a partir da secagem do leite de levedura, através do método de processamento "spray dry", fornecido pela copersucar.

A levedura desidratada foi incorporada às rações em detrimento do milho e do farelo de soja, mantendo as rações isoproteicas em cada fase do desenvolvimento dos animais, o farelo de casca de arroz foi utilizado para que as rações fossem também, isocalóricas em cada fase.

A água $e$ as rações foram fornecidas à vontade aos animais, durante o período experimental. Os pesos individuais e os dados de consumo de ração, foram coletados a cada duas semanas. A conversão alimentar foi obtida a partir da ingestão total de ração e do ganho de peso, no período, também de duas semanas. 
O experimento foi conduzido em um galpão experimental com 32 baias de $1,20 \times 3,00 \mathrm{~m}$, com piso parcialmente ripado, contendo comedouros e bebedouros automáticos.

Os animais foram distribuídos aos tratamentos de acordo com o peso, sexo e grupo genético, utilizando-se o delineamento experimental em blocos casualizados.

No final do período experimental, os animais foram abatidos e as características de carcaça foram avaliadas de acordo com o método de classificação de carcaças, adotado pela Associação Brasileira de Criadores de Suínos (1973).

\subsection{0 experimento e seu objetivo}

O objetivo deste experimento foi estudar a levedura desidratada, como fonte de proteina para suínos em crescimento e terminação, utilizando ração farelada.

Setenta e oito animais ( 36 machos castrados e 42 fêmeas) foram submetidos aos seguintes tratamentos:

T 1 - Ração controle, a base de milho e farelo de soja.

T 2 - Ração a base de milho e farelo de soja, contendo $3,50 \%$ da levedura desidratada.

T 3 - Ração a base de milho e farelo de soja, contendo $7,00 \%$ da levedura desidratada.

T 4 - Ração a base de milho e farelo de soja, contendo 10,50\% da levedura desidratada.

T 5 - Ração a base de milho e farelo de soja, contendo $14,00 \%$ da levedura desidratada. 
T 6 - Ração a base de milho e farelo de soja, contendo $17,50 \%$ da levedura desidratada.

Foram utilizados cinco repetições por tratamento, sendo que cada baia continha três (blocos 1,2, e 3) ou dois (blocos 4 e 5) animais. Do total de 78 animais que iniciaram o experimento, 5 foram retirados, pois quatro deles apresentaram prolapso do reto e um morreu, conforme mostra a Tabela 2.

Nas fases de crescimento (de 28,0 a $60,3 \mathrm{~kg}$ de peso médio) e terminação (de 60,3 a $94,0 \mathrm{~kg}$ de peso médio), os animais receberam rações contendo respectivamente, 17,5 e $15,5 \%$ de proteina bruta e 3251 e $3274 \mathrm{kcal}$ de energia digestível $/ \mathrm{kg}$.

A composição química e em aminoácidos da levedura desidratada é apresentada na Tabela 3 e a composição percentual das rações de crescimento e de terminação são apresentadas nas Tabelas 4 e 5.

No final do periodo experimental, após 24 horas de jejum, os animais foram pesados e enviados ao abatedouro. No abatedouro, eles foram sangrados e depilados, as carcaças foram serradas longitudinalmente ao meio e as vísceras, rins e gorduras dos rins, foram retiradas, deixando as caudas por convenção nas meias carcaças esquerdas.

As duas meias carcaças foram identificadas, pesadas e acondicionadas em uma câmara fria, onde permaneceram pelo espaço aproximado de 16 horas, a uma temperatura de 2 a $4^{\circ} \mathrm{C}$.

Após este período de refrigeração, as duas meias carcaças foram pesadas e as seguintes medidas e cortes foram feitos:

a) Comprimento de carcaça (CC), medida que compreende 0 espaço entre o bordo cranial da sínfise pubiana ao bordo cranial ventral do atlas (Figura 2).

b) Espessura de toucinho (ET) na $1^{\text {a }}$. costela, medida tomada perpendicularmente à linha dorso-lombar, na altura da porção média da $1^{a}$. vértebra torácica (Figura 3). 
Tabela 2. Distribuição dos animais por tratamento nos blocos, no final do período experimental.

\begin{tabular}{|c|c|c|c|c|c|c|}
\hline & \multicolumn{6}{|c|}{ Níveis de inclusão da levedura desidratada na ração, \% } \\
\hline Blocos & 0,0 & 3,5 & 7,0 & 10,5 & 14,0 & 17,5 \\
\hline 1 & 02 & 02 & 03 & 03 & 03 & 01 \\
\hline 1 & 03 & 03 & 02 & 03 & 03 & 03 \\
\hline 3 & 03 & 03 & 03 & 03 & 03 & 03 \\
\hline 4 & 02 & 02 & 02 & 02 & 02 & 02 \\
\hline 5 & 02 & 02 & 02 & 02 & 02 & 02 \\
\hline Total & 12 & 12 & 12 & 13 & 13 & 11 \\
\hline
\end{tabular}


Tabela 3. Composição química e em aminoácidos da levedura desidratada.

\begin{tabular}{lr}
\hline Item & \\
\hline Matéria seca, \% & 93,09 \\
Proteina bruta, \% & 42,81 \\
Fibra bruta, \% & 1,08 \\
Extrato etéreo, \% & 0,27 \\
Matéria minera, \% & 3,01 \\
Cálcio, \% & 0,18 \\
Fósforo total, \% & 0,57 \\
Magnésio, \% & 0,19 \\
Sódio, \% & 0,03 \\
Potássio, \% & 0,58 \\
Ferro, mg/kg & 88,33 \\
Zinco, mg/kg & 95,28 \\
Cobre, mg/kg & 11,08 \\
Maganês, mg/kg & 7,93 \\
Selênio, mg/kg & 1,30 \\
Níquel, mg/kg & 1,33 \\
Cobalto, mg/kg & 0,94 \\
Alanina, \% & 2,63 \\
Arginina, \% & 2,07 \\
Ácido aspártico, \% & 4,44 \\
Glicina, \% & 1,86 \\
Isoleucina, \% & 2,24 \\
Leucina, \% & 3,36 \\
Ácido glutâmico, \% & 4,81 \\
Lisina, \% & 3,65 \\
Cistina, \% & 0,52 \\
Metionina, \% & 0,85 \\
Fenilalanina, \% & 2,11 \\
Treonina, \% & 2,40 \\
Triptofano, \% & 0,51 \\
Valina, \% & 2,61 \\
Histidina, \% & 1,06 \\
Serina, \% & 2,24 \\
\hline Analserealzada \\
\hline
\end{tabular}

Análise realizada pelo laboratório da Mogiana Alimentos SA. 
Tabela 4. Composição percentual das rações de crescimento.

\begin{tabular}{|c|c|c|c|c|c|c|}
\hline \multirow[b]{2}{*}{ Ingredientes } & \multicolumn{6}{|c|}{ Níveis de inclusão da levedura desidratada na ração, \% } \\
\hline & 0,0 & 3,5 & 7,0 & 10,5 & 14,0 & 17,5 \\
\hline Milho & 71,70 & 71,22 & 70,82 & 70,22 & 69,69 & 69,23 \\
\hline Farelo de soja & 24,53 & 21,33 & 18,00 & 14,80 & 11,60 & 8,27 \\
\hline Levedura desidrtada & - & 3,50 & 7,00 & 10,50 & 14,00 & 17,50 \\
\hline Casca de arroz & - & 0,18 & 0,41 & 0,71 & 0,94 & 1,23 \\
\hline Fosfato bicálcico & 1,60 & 1,60 & 1,60 & 1,60 & 1,60 & 1,60 \\
\hline Calcário & 1,20 & 1,20 & 1,20 & 1,20 & 1,20 & 1,20 \\
\hline Sal & 0,50 & 0,50 & 0,50 & 0,50 & 0,50 & 0,50 \\
\hline Caulim & 0,07 & 0,07 & 0,07 & 0,07 & 0,07 & 0,07 \\
\hline Colina & 0,03 & 0,03 & 0,03 & 0,03 & 0,03 & 0,03 \\
\hline Sulfato de cobre & 0,05 & 0,05 & 0,05 & 0,05 & 0,05 & 0,05 \\
\hline \multicolumn{7}{|l|}{ Suprenox $10 \%$} \\
\hline (Olaquindox) & 0,05 & 0,05 & 0,05 & 0,05 & 0,05 & 0,05 \\
\hline Tylan S 100 & 0,10 & 0,10 & 0,10 & 0,10 & 0,10 & 0,10 \\
\hline Premix vitamínico & 0,07 & 0,07 & 0,07 & 0,07 & 0,07 & 0,07 \\
\hline Premix mineral & 0,10 & 0,10 & 0,10 & 0,10 & 0,10 & 0,10 \\
\hline \multicolumn{7}{|l|}{ Valores calculados } \\
\hline $\mathrm{ED} \mathrm{kcal} / \mathrm{kg}$ & 3.251 & 3.252 & 3.251 & 3.253 & 3.251 & 3.250 \\
\hline PB, \% & 17,50 & 17,50 & 17,50 & 17,50 & 17,50 & 17,50 \\
\hline Lisina, \% & 0,87 & 0,90 & 0,94 & 0,97 & 1,01 & 1,04 \\
\hline Treonina, \% & 0,67 & 0,70 & 0,72 & 0,75 & 0,78 & 0,80 \\
\hline Metionina, \% & 0,30 & 0,31 & 0,32 & 0,33 & 0,33 & 0,34 \\
\hline
\end{tabular}

${ }^{a}$ Suprindo as seguintes quantidades por $\mathrm{kg}$ de ração: vit. $A, 8000 \mathrm{Ul}$; vit. $D_{3}, 1500 \mathrm{Ul}$; vit. $E_{1} 18 \mathrm{mg}$; vit. $K_{3}, 2 \mathrm{mg}$; tiamina, $1,5 \mathrm{mg}$; riboflavina, $40 \mathrm{mg}$; piridoxina, $15 \mathrm{mg}$; cianocobalamina, $18 \mathrm{mcg}$; ácido fólico, $0,4 \mathrm{mg}$; biotina, $0,1 \mathrm{mg}$; pantontenato da cálcio, $15 \mathrm{mg}$; niacina, $30 \mathrm{mg}$; antioxidante, $0,015 \mathrm{mg}$ e selênio, $12 \mathrm{mg}$.

${ }^{b}$ Suprindo as seguintes quantidades por kg de ração: $\mathrm{Mn}, 45 \mathrm{mg}$, Fe, 88 mg; Cu, 15 $\mathrm{mg} ; \mathrm{Zn}, 80 \mathrm{mg} \mathrm{e} \mathrm{I,} 0,04 \mathrm{mg}$. 
Tabela 5 . Composição percentual das rações de terminação.

\begin{tabular}{|c|c|c|c|c|c|c|}
\hline \multirow[b]{2}{*}{ Ingredientes } & \multicolumn{6}{|c|}{ Niveis de inclusão da levedura desidratada na ração, \% } \\
\hline & 0,00 & 3,50 & 7,00 & 10,50 & 14,00 & 17,50 \\
\hline Milho & 77,32 & 76,83 & 76,27 & 75,77 & 75,22 & 74,72 \\
\hline Farelo de soja & 19,00 & 15,70 & 12,44 & 9,22 & 6,00 & 2,78 \\
\hline Levedura & --.---- & 3,50 & 7,00 & 10,50 & 14,00 & 17,50 \\
\hline Casca de arroz & 0,05 & 0,34 & 0,66 & 0,88 & 1,15 & 1,37 \\
\hline Fosfato bicálcico & 1,60 & 1,60 & 1,60 & 1,60 & 1,60 & 1,60 \\
\hline Calcário & 1,20 & 1,20 & 1,20 & 1,20 & 1,20 & 1,20 \\
\hline Sal & 0,50 & 0,50 & 0,50 & 0,50 & 0,50 & 0,50 \\
\hline Caulim & 0,05 & 0,05 & 0,50 & 0,05 & 0,05 & 0,05 \\
\hline Colina & 0,02 & 0,02 & 0,02 & 0,02 & 0,02 & 0,02 \\
\hline Sulfato de cobre & 0,05 & 0,05 & 0,05 & 0,05 & 0,05 & 0,05 \\
\hline \multicolumn{7}{|l|}{ Suprenox $10 \%$} \\
\hline (Olaquindox) & 0,06 & 0,06 & 0,06 & 0,06 & 0,06 & 0,06 \\
\hline Premix vitamínico & 0,05 & 0,05 & 0,05 & 0,05 & 0,05 & 0,05 \\
\hline Premix mineral & 0,10 & 0,10 & 0,10 & 0,10 & 0,10 & 0,10 \\
\hline \multicolumn{7}{|l|}{ Valores calculados: } \\
\hline ED kcal $/ \mathrm{kg}$ & 3.276 & 3.274 & 3.273 & 3.274 & 3.273 & 3.274 \\
\hline PB, \% & 15,50 & 15,50 & 15,50 & 15,50 & 15,50 & 15,50 \\
\hline Lisina, $\%$ & 0,72 & 0,76 & 0,79 & 0,83 & 0,86 & 0,89 \\
\hline Treonina, $\%$ & 0,60 & 0,62 & 0,65 & 0,68 & 0,71 & 0,73 \\
\hline Metionina, \% & 0,28 & 0,28 & 0,29 & 0,30 & 0,31 & 0,32 \\
\hline
\end{tabular}

${ }^{a}$ Suprindo as seguintes quantidades por kg de ração: vit. $A, 8000$ Ul; vit. $D_{3}, 1500$ Ul; vit. $E$, $18 \mathrm{mg}$; vit. $\mathrm{k}_{3}, 2 \mathrm{mg}$; tiamina, $1,5 \mathrm{mg}$; riboflavina, $40 \mathrm{mg}$; piridoxina, $15 \mathrm{mg}$; niacina, $30 \mathrm{mg}$; antioxidante, $0,015 \mathrm{~g}$, selênio, $12 \mathrm{mg}$.

${ }^{b}$ Suprindo, as seguintes quantidades por kg de ração: $\mathrm{Mn}, 45 \mathrm{mg} ; \mathrm{Fe}, 88 \mathrm{mg}$; $\mathrm{Cu}, 15 \mathrm{mg} ; \mathrm{Zn}$ $80 \mathrm{mg}$ e $1,0,04 \mathrm{mg}$ 
c) Espessura de toucinho na ultima costela, medida tomada na altura da interseção da ultima vértebra torácica com a primeira lombar, perpendicularmente a linha dorso lombar (Figura 3).

d) Espessura de toucinho na ultima vértebra lombar, efetuada na altura da articulação da penúltima vértebra lombar com a última, perpendicularmente à linha lombar (Figura 4.)

e) Área de olho de lombo (AOL) e gordura correspondente (Figura 4). O corte para as medidas foram feitos no mesmo local onde foi efetuado a medida da espessura de toucinho na última costela (Figura 5). Após o corte, a área de olho de lombo foi desenhada juntamente com a cobertura de gordura correspondente, incluindo o couro, para se obter a relação gordura carne $(\mathrm{RG} / \mathrm{C})$.

f) Peso do pernil (PsP). Para a separação do pernil da carcaça, foi serrado a articulação entre a última e a penúltima vértebra lombar (mesmo local da medida da espessura de toucinho) (Figura 5), e o pernil foi pesado, com cauda e pata (Figura 6). 


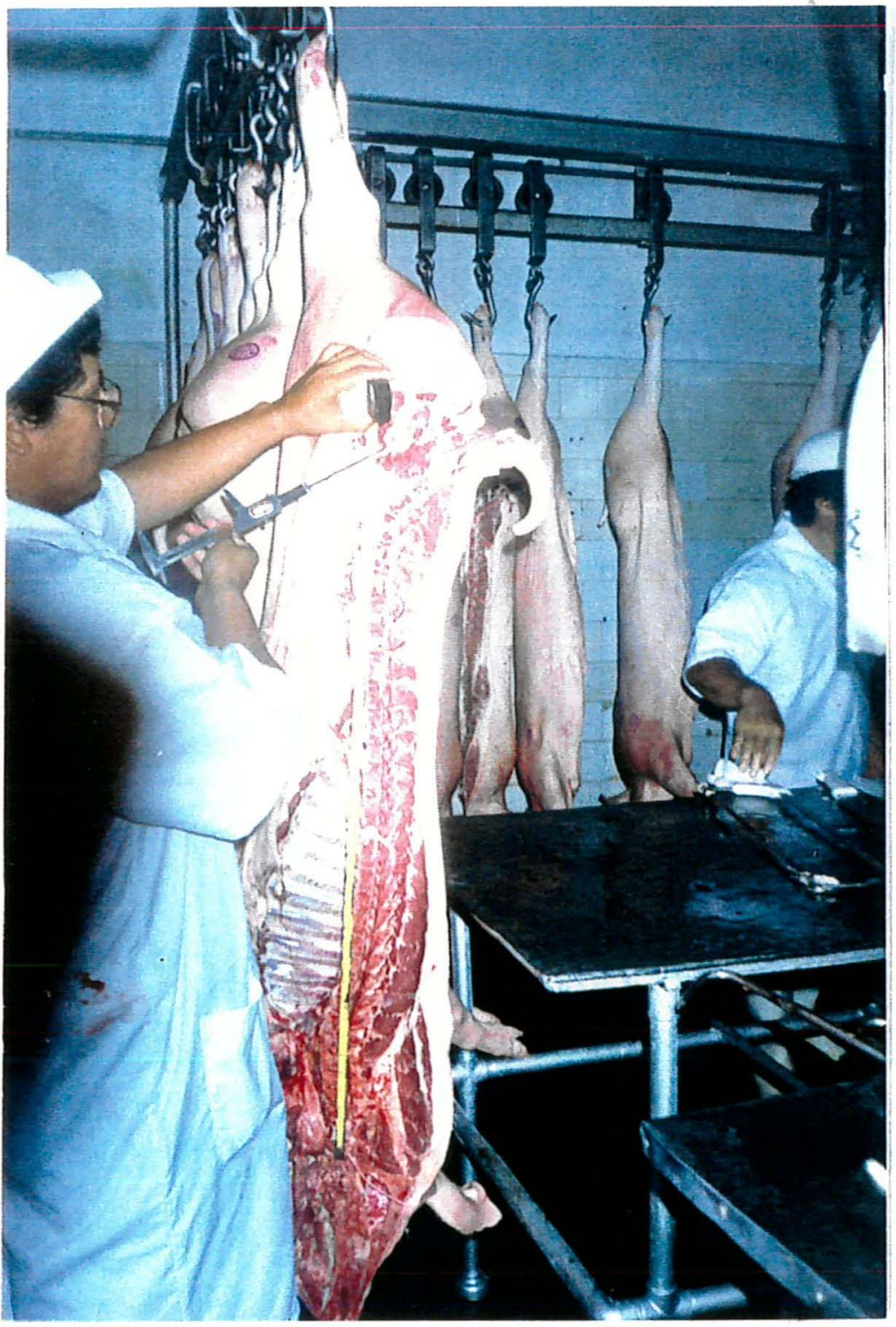

Figura 2 - Comprimento de carcaça. 

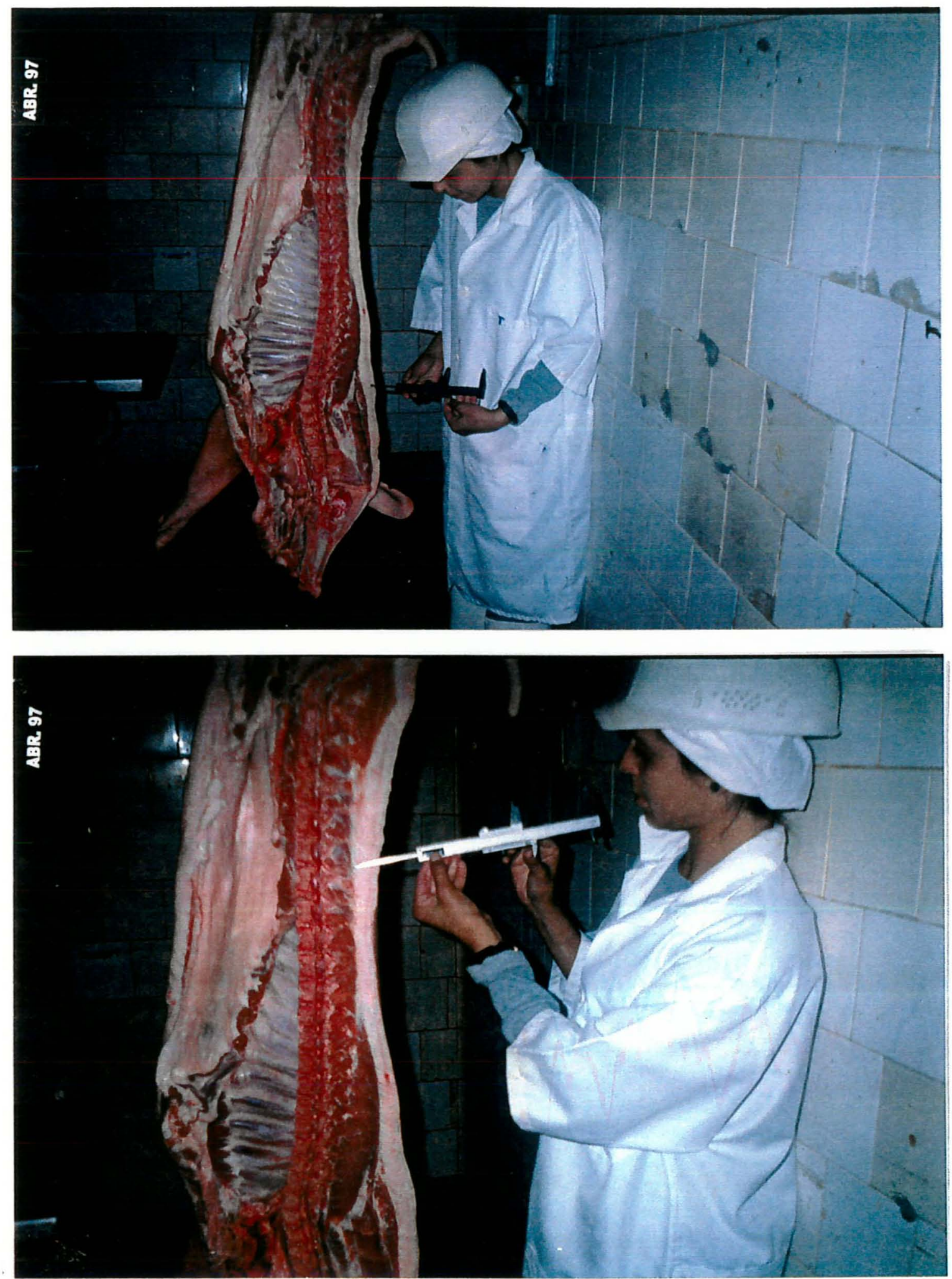

Figura 3 - Medidas de espessura de toucinho na primeira e última vértebras torácicas. 

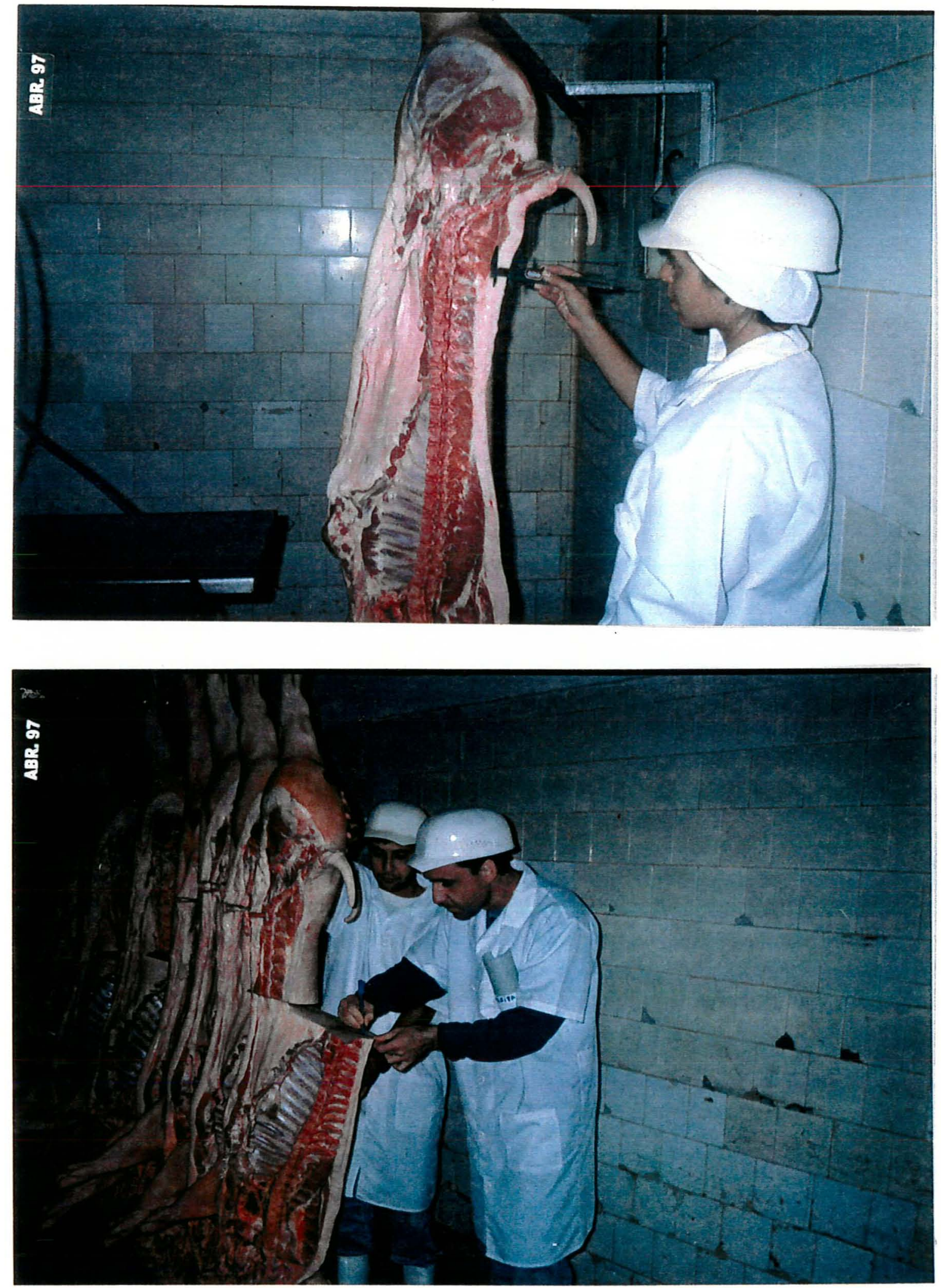

Figura 4 - Medidas de espessura de toucinho entre a penúltima e última vértebras lombares e da área de olho de lombo. 


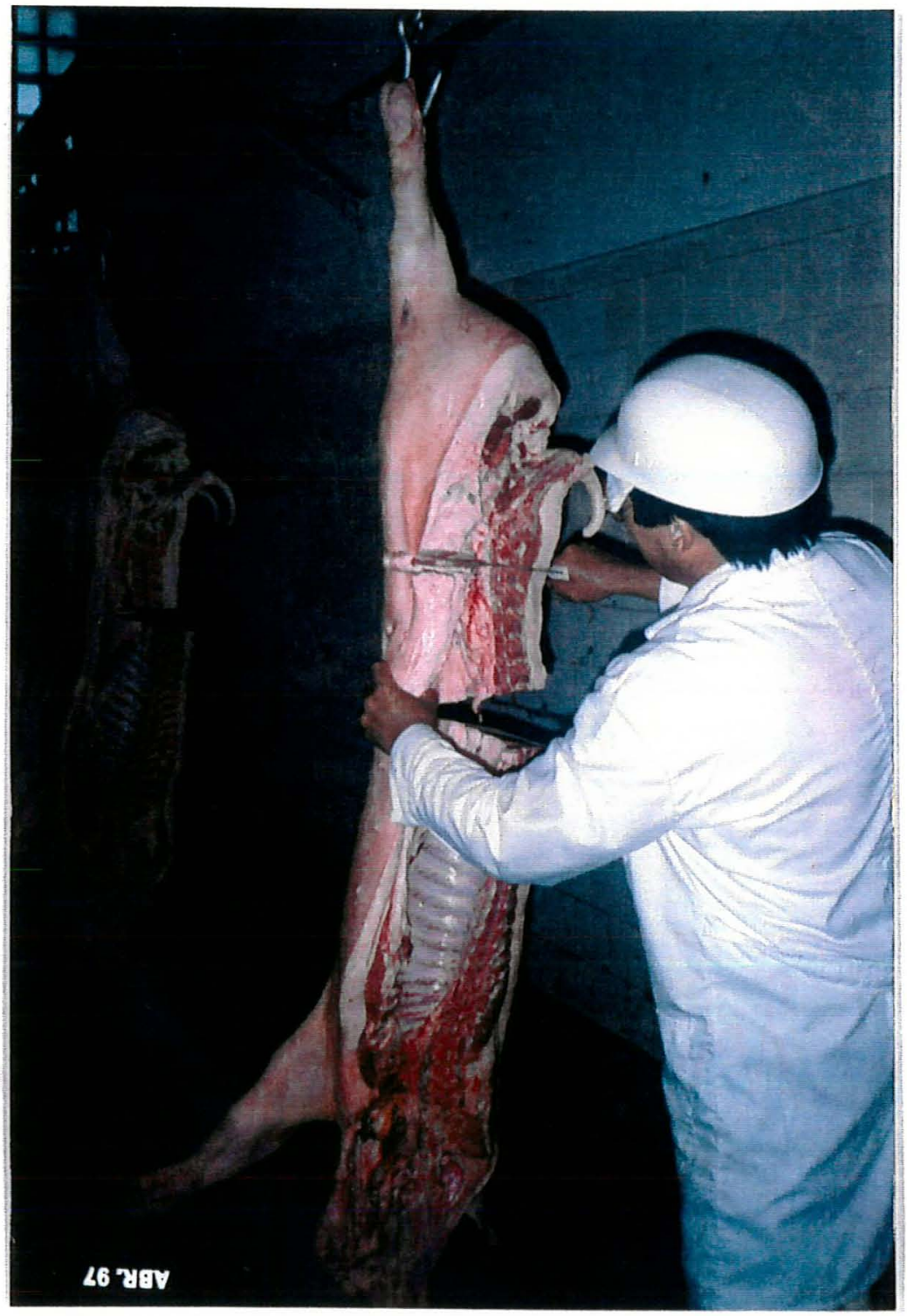

Figura 5 - Separação do pernil. 


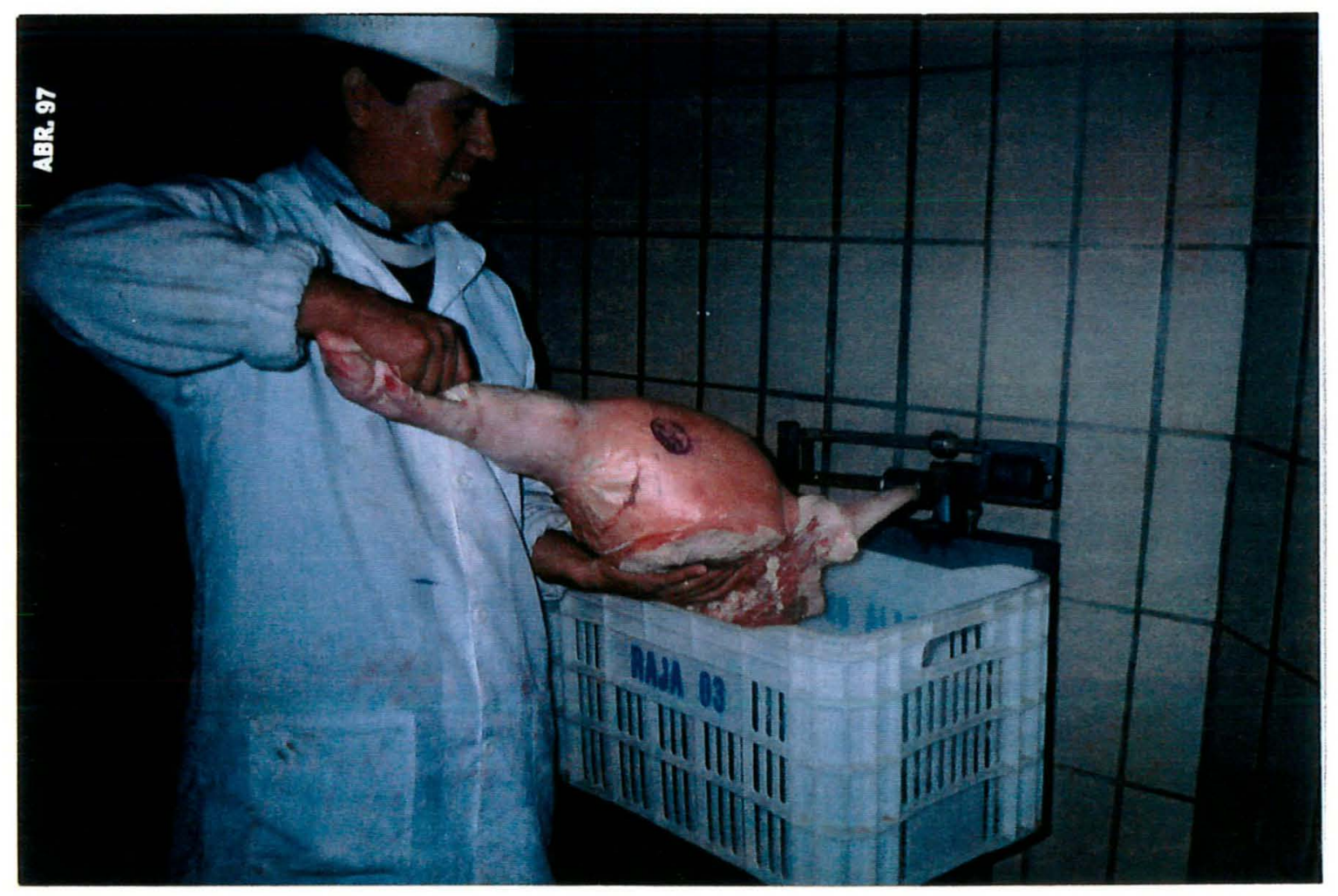

Figura 6 - Pesagem do pernil. 
A partir desses dados foram feitos os seguintes cálculos:

a) RENDIMENTO DE CARCAÇA (RC) = razão entre o peso da carcaça fria e o peso de abate, dado em porcentagem.

b) PERCENTAGEM DE PERNIL (PP) = razão entre o peso do pernil e o peso da meia carcaça correspondente, cortada ao meio.

c) RELAÇÃO GORDURA CARNE (RGC) = Razão entre a área de toucinho correspondente ao lombo e a área do músculo longissimus dorsi.

$O$ delineamento estatístico utilizado, foi o de blocos casualizados, contendo 6 tratamentos e 5 repetições.

Os dados de performance e característica de carcaças foram analisados através do módulo LAB do SAS INSTITUTE (1992), para avaliar o efeito do modelo. Após esta avaliação, os dados de performance [ganho diário de peso (GDP), consumo diário de ração (CDR) e conversão alimentar (CA)] foram submetidos a uma análise da variância, através do PROC GLM do SAS INSTITUTE (1983) e os dados de carcaça (RC, CC, ET, PP, AOL e RG/C) foram submetidos a uma análise de covariância, usando o peso de abate como covariável. Ambos os conjuntos de dados (performance e característica de carcaças) foram submetidos posteriormente a uma análise de regressão polinomial. 


\section{RESULTADOS E DISCUSSÃO}

Nas Tabelas 6, 7 e, 8 são apresentados os resultados das variáveis CA, GDP e CDR, referentes às fases de crescimento, terminação e período total, enquanto que os dados originais encontram-se nas Tabelas A1, A2 e A3 do apêndice.

O GDP dos animais, que receberam niveis crescentes da levedura desidratada, piorou linearmente em todas as fases estudadas: crescimento $(P=$ 0,$\left.0252 ; G D P=1,0205-0,0124 X ; R^{2}=0,69\right)$, terminação $(P=0,0147 ; G D P=1,1036$ - 0,0182X; $\left.R^{2}=0,68\right)$ e período total ( $P=0,0182 ; G D P=1,0619$ - 0,0156X; $\mathrm{R}^{2}=0,76$ ), conforme mostra a Figura 7. Embora tenha sido observado um efeito linear negativo da levedura sobre o GDP, uma análise considerando apenas os grupos que receberam niveis crescentes da levedura desidratada, pode-se observar que o nivel de $7 \%$ proporcionou o melhor GDP. Este resultado concorda com aquele obtido por Moreira et al. (1996), que também observaram uma piora no GDP dos suínos com o aumento do nivel de levedura na ração. Por outro lado, Bowman \& Veum (1973) e Tegbe \& Zimmerman (1977) não observaram qualquer efeito da levedura sobre o GDP de suínos em crescimento e terminação. Além desses pesquisadores, outros também relataram efeitos não significativos da levedura seca sobre o GDP dos suínos em recria ou em crescimento e terminação (Miyada \& Lavorenti, 1979; Moreira, 1984; Berto, 1985; Nunes, 1988; Miyada et al., 1992, 1997). Tais resultados têm sido observados, ora com rações isoproteicas, ora com rações 
Tabela 6. Médias de desempenho dos suinos na fase de crescimento.

\begin{tabular}{lccccccc}
\hline Variáveis & \multicolumn{6}{c}{ Níveis de inclusão da levedura desidratada na ração, \% } \\
\cline { 2 - 5 } & 0,00 & 3,50 & 7,00 & 10,50 & 14,00 & 17,5 & $\mathrm{CV}, \%^{\mathrm{b}}$ \\
\hline $\mathrm{CA}^{\mathrm{a}}$ & 2,31 & 2,34 & 2,44 & 2,52 & 2,50 & 2,54 & 4,84
\end{tabular}

GDP,

$\mathrm{kg}^{\mathrm{a}}$

$1,017 \quad 0,970$

0,998

0,983

0,949

0,946

4,92

CDR,

$\mathrm{kg}$

$2,36 \quad 2,29$

$2,44 \quad 2,48$

$2,34 \quad 2,45$

5,89

\footnotetext{
${ }^{a}$ Efeito linear da levedura desidratada na CA $(P=0,0011)$ e no GDP $(P=0,0252)$.

${ }^{b}$ Coeficiente de variação.
} 
Tabela 7. Médias de desempenho dos suínos na fase de terminação.

\begin{tabular}{lllllllll}
\hline Variáveis & \multicolumn{8}{c}{ Níveis de inclusão da levedura desidratada na ração, \% } \\
\cline { 2 - 6 } & 0,0 & 3,50 & 7,00 & 10,50 & 14,00 & 17,50 & CV, \% \\
\hline CA & 2,92 & 2,94 & 2,81 & 2,97 & 3,09 & 2,88 & 5,97
\end{tabular}

GDP,

$\mathrm{kg}^{\mathrm{a}}$

$1,094 \quad 1,048$

1,080

1,013

$0,990 \quad 1,015$

6,13

CDR,

$\mathrm{kg}$

3,19

3,07

3,03

3,02

3,07

2,93

9,29

\footnotetext{
${ }^{2}$ Efeito linear da levedura desidratada no GDP $(P=0,0147)$.

${ }^{b}$ Coeficiente de variação.
} 
Tabela 8. Médias de desempenho dos suínos no período total.

\begin{tabular}{|c|c|c|c|c|c|c|c|}
\hline \multirow{2}{*}{ Variáveis } & \multicolumn{6}{|c|}{ Niveis de inclusão da levedura desidratada na ração, \% } & \multirow[b]{2}{*}{$\mathrm{CV}, \%{ }^{\mathrm{b}}$} \\
\hline & 0,00 & 3,50 & 7,00 & 10,50 & 14,00 & 17,50 & \\
\hline $\mathrm{CA}^{\mathrm{a}}$ & 2,62 & 2,64 & 2,62 & 2,76 & 2,80 & 2,72 & 3,79 \\
\hline \multicolumn{8}{|l|}{ GDP, } \\
\hline $\mathrm{kg}^{\mathrm{a}}$ & 1,054 & 0,995 & 1,036 & 0,999 & 0,968 & 0,978 & 5,15 \\
\hline \multicolumn{8}{|l|}{ CDR, } \\
\hline $\mathrm{kg}$ & 2,76 & 2,60 & 2,72 & 2,75 & 2,72 & 2,69 & 7,61 \\
\hline
\end{tabular}

\footnotetext{
${ }^{2}$ Efeito linear para CA $(P=0,0090)$ e Efeito linear para GDP $(P=0,0182)$.

${ }^{b}$ Coeficiente de variação.
} 


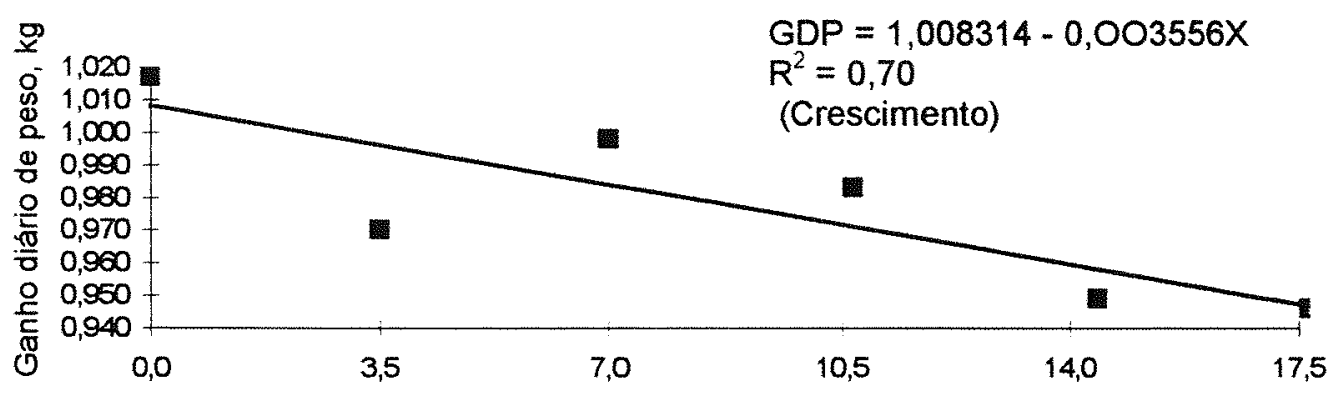

Niveis de inclusão da levedura desidratada na ração, \%
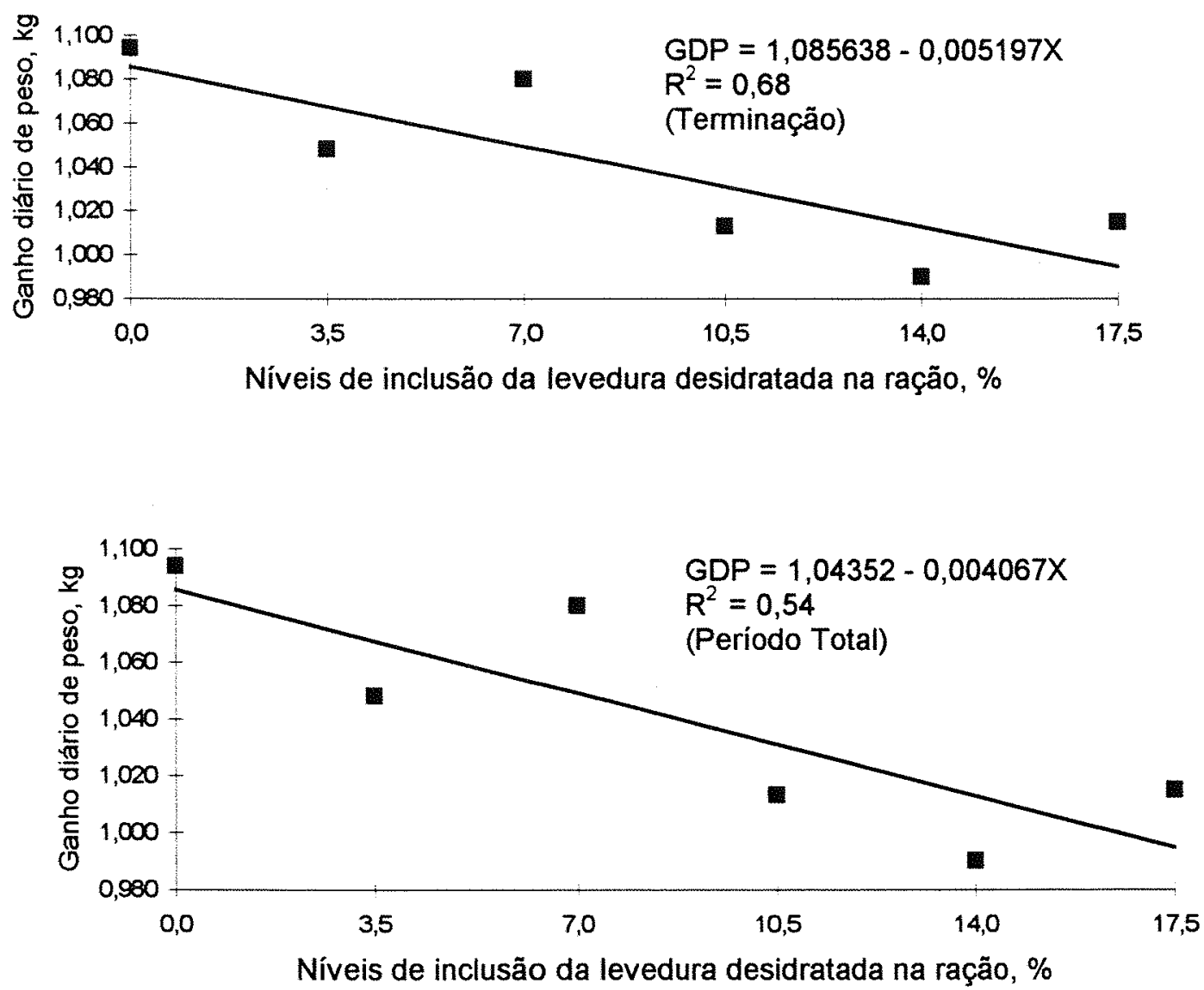

Figura 7-Efeitos dos niveis de inclusão da levedura desidratada na ração sobre o ganho diário de peso (GDP) dos suínos nas fases de crescimento, terminação e período total. 
isoprotéicas e isocalóricas (Miyada \& Lavorenti, 1979; Moreira, 1984; Berto, 1985). Na realidade, as diferenças nos resultados dos diversos trabalhos podem ser devido a variações nos tipos de leveduras utilizados.

Uma vez que, mesmo com um CDR semelhante, obteve-se um efeito depressivo no desempenho, pode-se sugerir que a levedura desidratada piorou o valor nutritivo das rações, conforme mostra o GDP. Tal fato pode ter sido consequência de a levedura, utilizada neste experimento, apresentar conteúdo de energia digestível abaixo daquele utilizado como base de cálculo das rações de crescimento e terminação. É importante ressaltar, ainda, que a parede celular é um dos principais responsáveis pelo baixo valor nutritivo de algumas leveduras, pois, quando intata, ela dificulta a utilização de proteinas e outros nutrientes do citoplasma. Além disso, cerca de $35 \%$ do total de aminoácidos podem estar ligados à parede celular. Em ambas as situações, a digestibilidade e a biodisponibilidade dos nutrientes ficam sensivelmente prejudicadas (Butolo, 1997).

Neste experimento não foram observados efeitos significativos $(P>0,05)$ dos níveis de levedura desidratada sobre o $C D R$. Este resultado está de acordo com os apresentados por Moreira (1984), Nunes (1988), Landell Filho et al. (1994), Moreira et al. (1996). Por outro lado, nos trabalhos de Miyada \& Lavorenti (1979) e Berto (1985) foram observados aumentos no CDR com a utilização de níveis crescentes (até 28\%) da levedura desidratada. Outras pesquisas, no entanto, mostraram aumento no CDR apenas até o nivel 13\% de levedura seca na ração (Miyada et al., 1992; Landell Filho et al., 1993a). A redução no conteúdo energético das rações, à medida que a levedura seca substituiu ingredientes como farelo de soja e milho, foi apontada por alguns autores como a responsável pelo aumento no CDR de suínos em crescimento - terminação (Miyada \& Lavorenti, 1979) e recria (Berto, 1985). Miyada et al. (1992) sugeriram, também, que o aumento no consumo pode ter sido estimulado pela melhoria na palatabilidade da ração, ao contrário deste 
experimento, onde não se constatou diferença significativa no CDR entre os tratamentos estudados. $\dot{E}$ importante, ainda, ressaltar que 0 trabalho desenvolvido por Tebge \& Zimmerman (1977), ao contrário deste experimento, evidenciou que a levedura pode proporcionar a obtenção de rações com consistência pegajosa na boca dos animais, dificultando, assim, a sua ingestão.

Comparações feitas entre a forma física das rações (farelada e peletizada), até o nivel de $30 \%$ de levedura seca na ração, não mostraram diferença no CDR de leitões em recria (Miyada et al., 1992), indicando que a textura desta ração pode não ter influência no consumo. Neste experimento, mesmo utilizando apenas a forma farelada, não se observou efeito significativo dos niveis de levedura desidratada (até 17,5\%) sobre o CDR de suínos em crescimento e terminação.

Submetendo os dados de CA à análise de regressão polinomial, observou-se um efeito linear depressivo da levedura desidratada na fase de crescimento $\left(P=0,0011 ; C A=2,2707+0,0489 X ; R^{2}=0,89\right)$ e no período total $\left(P=0,0090 ; C A=2,5827+0,0326 X ; R^{2}=0,60 ;\right.$ Figura 8$)$, enquanto que, na fase de terminação, não foi constatado qualquer efeito significativo $(P>0,05)$ sobre esta variável. Conforme já citado anteriormente, uma vez que o CDR foi semelhante e o GDP e a CA pioraram linearmente com a inclusão da levedura desidratada à ração, esta queda na performance pode estar associada, possivelmente, ao menor conteúdo energético e/ou à pior digestibilidade dos nutrientes desta levedura, em função de sua parede celular. Resultados semelhantes também foram obtidos por Miyada \& Lavorenti (1979), Berto (1985), Miyada (1987), Nunes (1988), Miyada et al. (1992), Landell Filho et al., (1993a, 1994), trabalhando com níveis crescentes da levedura seca.

Neste experimento não foi observado efeito significativo $(P>0,05)$ para as variáveis $R C, C C, E T, P P, A O L$ e RG/C, conforme mostra a Tabela 5 dados originais Tabela A4, A5, A6, A7 e, A8 do apêndice. Estes resultados 

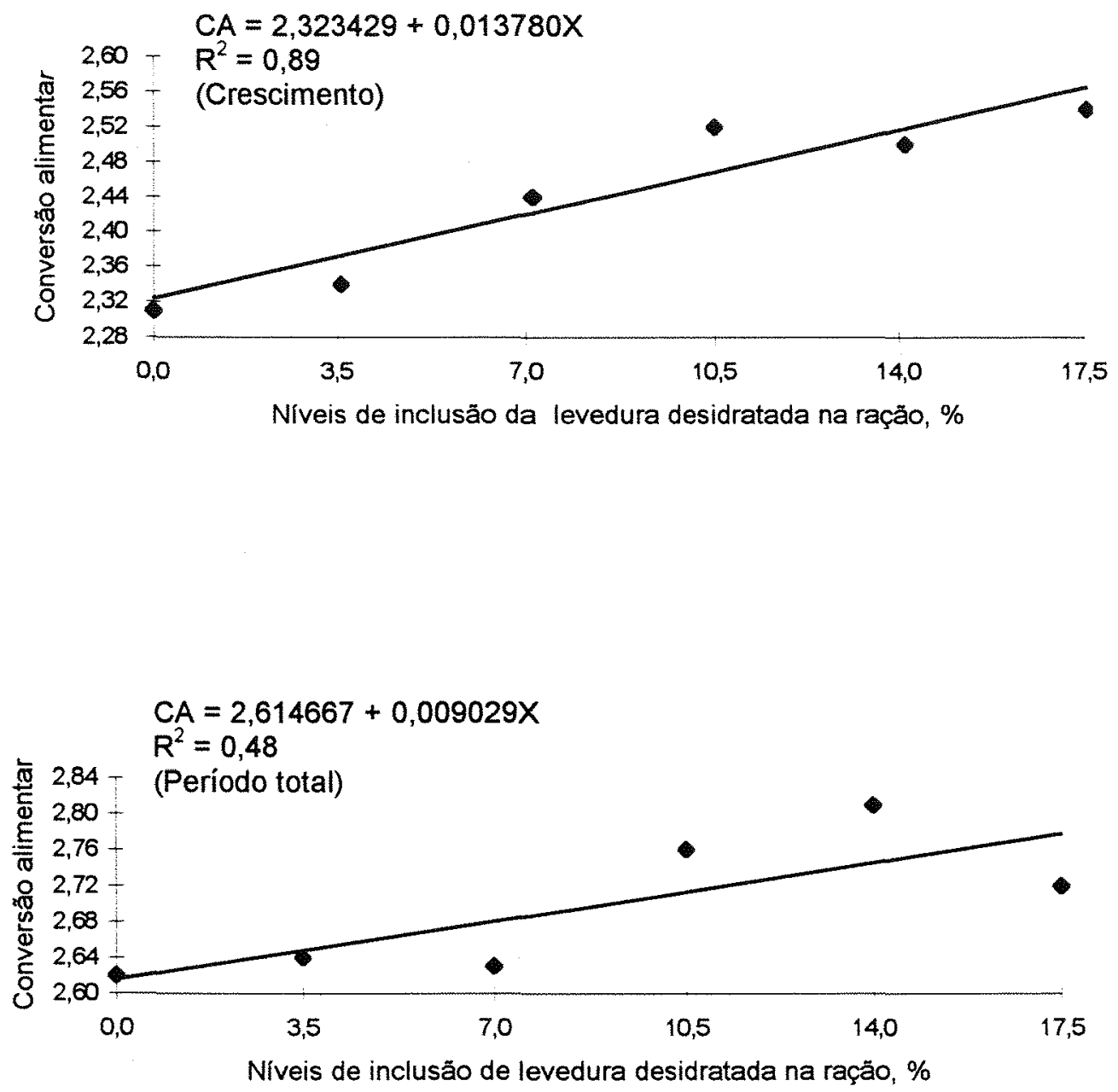

Figura 8-Efeito dos níveis de inclusão da levedura desidratada na ração sobre a conversão alimentar (CA) dos suínos na fase de crescimento e no período total. 
estão de acordo com aqueles obtidos por Moreira (1984), que não encontrou diferenças no desempenho e características de carcaça de suínos alimentados com rações isoprotéicas e isoenergéticas, contendo $0,5,10$, e $15 \%$ de levedura seca. Outros pesquisadores (Miyada, 1987; Landell Filho, 1993a; Citroni, 1995), também não observaram efeitos significativos da levedura seca sobre a maioria das características de carcaça, mesmo com a substituição total do farelo de soja em rações de crescimento e terminação. Por outro lado, Miyada \& Lavorenti (1979) observaram uma tendência geral para a obtenção de carcaças de melhor qualidade com o aumento da levedura seca nas rações de suínos em crescimento e terminação. Esta melhoria na qualidade de carcaça foi atribuída ao aumento do consumo de proteina e de lisina, em consequência da redução do nivel energético das rações, proporcionada pela incorporação da levedura. Embora, no presente experimento, o nível de lisina também tenha aumentado com a inclusão da levedura às rações, não ficaram caracterizados os efeitos benéficos deste aminoácido sobre o desempenho e as características de carcaça dos suínos em crescimento e terminação. Ressalte-se ainda, que têm sido observados, até mesmo, efeitos depressivos da levedura desidratada sobre a PP e AOL (Landell Filho et al., 1993a). 
Tabela 9 . Características de carcaça.

Niveis de inclusão da levedura na ração, \%

Variáveis

\begin{tabular}{llllll}
\hline 0,0 & 3,5 & 7,0 & 10,5 & 14,0 & 17,5
\end{tabular} CV, \%

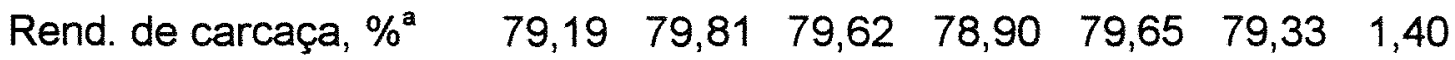

Comp. de carcaça, $\mathrm{cm}^{\mathrm{a}} \quad 95,00 \quad 93,45 \quad 94,55 \quad 93,33 \quad 94,48 \quad 94,84 \quad 2,66$

Esp. de toucinho, $\mathrm{cm}^{\mathrm{a}} \quad 2,78 \quad 3,03 \quad 2,91 \quad 2,80 \quad 3,03 \quad 2,85 \quad 11,70$

Percent. de pernil, \% ${ }^{a} \quad 34,77 \quad 35,51 \quad 35,51 \quad 35,43 \quad 34,51 \quad 34,28 \quad 5,48$

Área de lombo, $\mathrm{cm}^{2 \mathrm{a}} \quad 34,68 \quad 34,65 \quad 36,59 \quad 34,07 \quad 35,20 \quad 34,11 \quad 2,83$

$\begin{array}{llllllll}\text { Relação gordura/carne }^{a} & 0,53 & 0,57 & 0,49 & 0,52 & 0,56 & 0,56 & 18,63\end{array}$

\footnotetext{
${ }^{2}$ Médias ajustadas por covariância.
}

${ }^{b}$ Coeficiente de variação. 


\section{CONCLUSÕES}

Os niveis crescentes da levedura desidratada determinaram um efeito depressivo sobre o GDP e a CA, sem afetar o CDR. Por outro lado, dentre os niveis de levedura testados, o nivel de $7 \%$ foi o que apresentou melhores resultados, proporcionando um GDP e uma CA semelhantes àqueles obtidos no tratamento controle, indicando ser este o melhor nivel de utilização da levedura desidratada em rações de crescimento e terminação de suinos. Contudo, novas pesquisas devem ser realizadas, para avaliar a digestibilidade e a biodisponibilidade dos nutrientes da levedura processada pelo método "spray dry". 


\section{REFERÊNCIAS BIBLIOGRÁFICAS}

ASSOCIAÇÃO BRASILEIRA DE CRIADORES DE SUINOS. Método Brasileiro de classificação de carcaça. Estrela: ABCS, 1973. 17p.

ASPLUND, J.M.; PFANDER, W.H. Proccedings of Alternative Sources of Protein for Animal Production. National Academy of Sciences. p. 130145, 1973.

BHATTACHARJEE, J.K. Microorganisms as potencial source of food. Advanc. Appl. Microbiol.. v. 13, p. 139-161, 1970.

BERTO, D.A. Uso da levedura seca (Saccharomyces $s p$.) na alimentação de leitões em recria. Piracicaba, 1985. 133p. Dissertação (Mestrado.) - Escola Superior de Agricultura "Luiz de Queiroz", Universidade de São Paulo.

BOWMAN, G.L.; VEUM, T.L. Saccharomyces cerevisiae Yeasy culture in growing finishing swine diets, Journal of Animal Science., v. 37, n. 1, p. 72-74, 1973.

BUTOLO, J.E. Uso da levedura desidratada na alimentação de aves. In: SIMPÓSIO SOBRE TECNOLOGIA DA PRODUÇÃO E UTILIZAÇÃO DA LEVEDURA DESIDRATADA NA ALIMENTAÇĀO ANIMAL, Campinas, 1997. Anais. Campinas: CBNA, 1997. p. 51-84. 
CITRONI, A.R. Associação de fontes alternativas de proteínas na alimentação de suinos em crescimento e terminação. Piracicaba, 1995. 109p. Dissertação (Mestrado) - Escola Superior de Agricultura "Luiz de Queiroz" Universidade de São Paulo.

COZZOLINO, S.M.F. Valor nutricional da biomassa de Saccharomyces cerevisea. Estudo em gerações sucessivas de ratos. São Paulo, 1982. 147p. Tese (Doutorado) - Faculdade de Ciência Farmacêutica, Universidade de São Paulo.

CUNNINGHAM, S.D., CATER, C.M., MATTIL, E.K.F. Rupture and protein extraction of petroleum-grown yeast. J.Food Sci., v. 40: p. 732-735, 1975.

DESMONTS, R. Utilização do levedo na alimentação da criança. Pediatria prática, v. 39, n. 7, p. $7-18,1968$.

EMPRESA BRASILEIRA DE PESQUISA AGROPECUÁRIA. Tabela de Composicão química e valores energéticos de alimentos para suínos e aves. Concórdia: CNPSA, 1991, 97p.

FIALHO, E.T.; GOMES, P.C.; ALBINO, L.F.T.; COSTA, V. Determinação dos valores de composição química e de digestibilidade de alguns ingredientes nacionais para suínos. Revista da Sociedade Brasileira de Zootecnia, v. 12, p. 337-356, 1983.

FIALHO, E.T.; ALBINO, L.F.T.; BLUME, E. Composição química e valores energéticos de alguns alimentos para suínos. Pesquisa Agropecuária Brasileira, v. 20, p. 1419-1431, 1985. 
GESSULLI, O.P. A economia do ano 2000. Avicultura e Suinocultura Industrial, n. 971, p. 24-36, 1991.

GHIRALDINI, J. A.; ROSSELL, C. E.V. Caracterização e qualidade de levedura desidratada para a alimentação animal. In: SIMPÓSIO SOBRE TECNOLOGIA DA PRODUÇÃO E UTILIZAÇÃO DA LEVEDURA DESIDRATADA NA ALIMENTAÇÃO ANIMAL, Campinas, 1997. Anais. Campinas: CBNA, 1997. p. 27-50, 1997.

HANSSEN, J.T. Bioproteins in the feeding of growing-finishing pigs in norway. I. Chemical composition, nutrient digestibility and protein quality of "Pruteeen", "Tropina" "Pequilo" and methanol-base yeast products (Pichia aganobii). J. Anim. Physiol. And anim. Nutr., v. 46, p. 182-196, 1981.

HARPER, H. A. Manual de química fisiológica, São Paulo: Atheneu editora, São Paulo, 1982, 570p.

KRONKA, R. N.; CURTARELLI, S.M.; KRONKA, S.N.; ARCADEPANI, D.; RAMOS, I. Uso da levedura seca (Saccharomyces cerevisiae) de destilarias de álcool de cana-de-açucar e farelo de arroz na alimentação de suínos. In: XXIV REUNIÄO ANUAL DA SOCIEDADE BRASILEIRA DE ZOOTECNA, 24 Brasillia, 1987. Anais. Brasilia: SBZ, 1987. p. 1.

LANDELL FILHO, L.C.; KRONKA, R.N.; LIMA,G.J.M.M.; THOMAS,M.C. Utilização de levedura de centrifugação da vinhaça (Saccharomyces cerevisiae) como fonte de proteinas para suinos em crescimento e terminação. Revista da Sociedade Brasileira de zootecnia, V. 22, n. 6, p. 961-69, 1993a. 
LANDELL FILHO, L.C.; KRONKA, R.N.; THOMAS,M.C. ;CURTARELLI, S.M. Componentes sanguineos de suínos em crescimento e terminação, alimentados com raçōes contendo levedura de centrifugação da vinhaça (Saccharomyces cerevisiae). Revista da Sociedade Brasileira de Zootecnia, v. 22, n. 6, p. 969-979, 1993b.

LANDELL FILHO, L.C.; KRONKA, R.N.; THOMAS,M.C.; CURTARELLI, S.M. . Utilização da levedura e centrifugação da vinhaça (Saccharomyces cerevisiae), como fonte protéica para leitões na fase inicial (10 a $30 \mathrm{~kg}$ de peso vivo). Revista da Sociedade Brasileira de Zootecnia, v. 23, p. 283291, 1994.

LEHNINGER, A.L., Princípios da bioquímica. São Paulo: Sarvier, 1995, 839p.

LIMA, G.J.M.M. Uso da levedura seca (Saccharomyces cerevisiae) de destilaria de álcool de cana-de-açucar na alimentação de suínos em gestação e lactação. Piracicaba, 1983. 139p. Dissertação (Mestrado) - Escola Superior de Agricultura "Luiz de Queiroz", Universidade de São Paulo.

LIMA, R.A.S.; DUWE JR, R.; MIYADA, V.S.; NEVES, E.M.; AZEVEDO FILHO, A.J.B.V. Formulações econômicas de ração para suínos em acabamento e considerações sobre a utilização de levedura seca. O Solo. v. 79, p. 9-13, 1987.

MAYNARD, L.A.; LOSSLI, J.K. Nutrição Animal. São Paulo: Editora USAID, $1966,550 \mathrm{p}$. 
MENTEN, J.F.M.; LIMA, G.J.M.M.; PACKER, I.U.; MIYADA, V.S.; LAVORENTI, A Niveis de uréia e ácido úrico no sangue de porcas alimentadas com rações contendo levedura seca. In: REUNIÃO ANUAL DA SOCIEDADE BRASILEIRA DE ZOOTECNIA, 21, 1984, Belo Horizonte. Anais. Belo Horizonte: SBZ, 1984, p.204.

MIYADA, V.S.; LAVORENTI, A. Uso da levedura seca (Saccharomyces cerevisiae) de destilaria de álcool de cana-de-açucar na alimentação de suínos em crescimento e acabamento. Revista da Sociedade Brasileira de Zootecnia, v. 8, n. 3, p. 497-515, 1979.

MIYADA, V.S. A levedura seca na alimentação de suínos: estudos adicionais sobre o seu valor protéico e vitamínico. Piracicaba, 1987. 159p. Tese (LivreDocência) - Escola Superior de Agricultura "Luiz de Queiroz", Universidade de São Paulo.

MIYADA, V.S.; LAVORENTI, A.; PACKER, I.U. A levedura seca como ingrediente de rações fareladas ou peletizadas de leitões em recria. Revista da Sociedade Brasileira de Zootecnia, v. 21, n. 3, p. 439-447, 1992.

MIYADA, V.S.; LAVORENTI, A.; PACKER, I.U.; MENTEN, J.F.M. A levedura seca como fonte de proteína para leitões em recria (10 aos $28 \mathrm{~kg} P V$ ) Revista Brasileira de Zootecnia, v. 26, n. 2, p. 316-326, 1997.

MONTEIRO, J.Br.R.; SILVA, D.O.; MORAES, C.A. Produção de biomassa protéica de Trichoderma reesei e rhizopus oligosporus em bagaço de cana de açúcar. Revista Microbiologia, v. 22, n . 2, p. 164-169, 1991. 
MOREIRA, J.A. Uso da levedura seca (Saccharomyces cerevisiae) de destilarias de álcool de cana-de-açucar em rações isocalóricas para suínos em crescimento e acabamento. Piracicaba, 1984. 107p. Dissertação (Mestrado) - Escola Superior de Agricultura "Luiz de Queiroz", Universidade de São Paulo.

MOREIRA, I; ANDREOLI, F.L.; FURLAN, A.C. Niveis crescentes da levedura de recuperação (Saccharomyces spp.), seca pelo método "spray dry", na alimentação de leitões. In: REUNIÃO ANUAL DA SOCIEDADE BRASILEIRA DE ZOOTECNIA, 33, 1996, Fortaleza. Anais. Fortaleza: SBZ, 1996, p. $272-274$.

MOREIRA, I; ANDREOLI, F.L.; FURLAN, A.C. Utilização da levedura de recuperação seca por "spray dry", em rações fareladas ou peletizadas, na alimentação de leitões. In: REUNIÃO ANUAL DA SOCIEDADE BRASILEIRA DE ZOOTECNIA, 34, 1997, Juiz de Fora. Anais. Juiz de Fora: SBZ, 1997, p. 377-379.

NOBLE, N. Os microorganismo e o homem. São Paulo: editora EDUSP, 1981. v. $17,81 \mathrm{p}$.

NUNES, J.R.V. Uso de levedura de cana (Saccharomyces cerevisiae) na alimentação inicial de leitões. In: REUNIÃO ANUAL DA SOCIEDADE BRASILEIRA DE ZOOTECNIA, 34, 1988, Brasília. Anais. Brasilia: SBZ, 1988. p. 18.

PELCZAR, M. Microbiologia. São Paulo: editora MCGRAW -HILL, 1981, v. 1, $497 p$. 
PELCZAR, M. Microbiologia. São Paulo: editora MCGRAW - HILL, 1981,v. 2 , $530 \mathrm{p}$.

PINOTTI, R.F. Situação atual e perspectivas da produção da indústria sucroalcooleiro: - levedura. In: SIMPÓSIO SOBRE TECNOLOGIA DA PRODUÇÃO E UTILIZAÇÃO DA LEVEDURA DESIDRATADA NA ALIMENTAÇÃO ANIMAL, Campinas, 1997. Anais. Campinas: CBNA, 1997 p. 1-6.

RHEINBOLDT, P.H.H; LEIMER, K.H.; ROSSEL, C.E.V. Sangria e secagem de levedura - processo CTC. Boletim Técnico Coopersucar, Piracicaba, n. 9, p. 8-12, nov. 1987.

RHEINBOLDT, P.H.H.; LEIMER, K.H.; ROSSEL, C.E.V. Sangria e Secagem de levedura de destilaria - processo Copersucar. STAB, Açúcar, Álcool e Subprodutos, Piracicaba, v. 6, n. 2, p. 48-51, 1987.

STRYER, L. Bioquímica. Rio de Janeiro: Guanabara Koogan, 1992, 1089 p.

TEBGE, S.B.; ZIMMERMAN, D.R. Evaluation of a single cell protein in pig diets. Journal of Animal Science, v. 45, n. 6, p. 1309-1316, 1977.

VANANUVAT, P. Value of yeast for poultry feeds. Critical reviews in food sciencis and nutrition, v. 9, p. $325,1977$. 
ZANUTO, C.A.; MOREIRA, I.; FURLAN, A.C.; SCAPINELL, C.; MURAKAMI, A. E. Utilização da levedura de recuperação seca por rolo rotativo ou por "spray dry" na alimentação de leitões. REUNIÃO ANUAL DA SOCIEDADE BRASILEIRA DE ZOOTECNIA, 34, 1997, Juiz de Fora, Anais, Juiz de Fora: SBZ, 1997, p. 146-148.

WALDROUP, P.W.; HILLARD, C.M.; MITCHELL, R.J. The nutritive value of yeast grown on hydrocarbon fractions for broiler chicks. Poutry Science, v. 50, n. 1022-1029, 1971.

WASSERMAN, A.E., Amino acid and vitamin composition of Saccharomyces fragilis grow in whey. Journal Dairy Science., v. 44, p. 379-386, 1961. 
APÊNDICE 
Tabela A1. Desempenho de suínos na fase de crescimento.

Niveis de inclusão da levedura desidratada na ração, \%

$\begin{array}{llllllll}\text { Variáveis }^{\mathrm{a}} & \text { Bloco } & 0,00 & 3,50 & 7,00 & 10,50 & 14,00 & 17,50\end{array}$

\begin{tabular}{|c|c|c|c|c|c|c|c|}
\hline & 1 & 1,017 & 0,980 & 0,956 & 0,982 & 0,993 & 0,950 \\
\hline & 2 & 1,118 & 0,975 & 0,966 & 0,983 & 0,930 & 1,073 \\
\hline \multirow[t]{6}{*}{ GDP, kg } & 3 & 0,994 & 0,947 & 1,019 & 0,970 & 0,966 & 0,967 \\
\hline & 4 & 1,013 & 0,983 & 1,037 & 0,976 & 0,934 & 0,844 \\
\hline & 5 & 0,945 & 0,967 & 1,010 & 1,002 & 0,923 & 0,896 \\
\hline & Média & 1,017 & 0,970 & 0,998 & 0,983 & 0,949 & 0,946 \\
\hline & 1 & 2,51 & 2,40 & 2,51 & 2,61 & 2,46 & 2,57 \\
\hline & 2 & 2,59 & 2,37 & 2,26 & 2,33 & 2,14 & 2,69 \\
\hline \multirow[t]{6}{*}{$\mathrm{CDR}, \mathrm{kg}$} & 3 & 2,34 & 2,24 & 2,52 & 2,48 & 2,46 & 2,30 \\
\hline & 4 & 2,27 & 2,22 & 2,51 & 2,37 & 2,42 & 2,28 \\
\hline & 5 & 2,07 & 2,22 & 2,39 & 2,62 & 2,38 & 2,43 \\
\hline & Média & 2,36 & 2,29 & 2,43 & 2,48 & 2,37 & 2,45 \\
\hline & 1 & 2,47 & 2,37 & 2,62 & 2,66 & 2,48 & 2,42 \\
\hline & 2 & 2,32 & 2,43 & 2,34 & 2,37 & 2,30 & 2,50 \\
\hline \multirow[t]{4}{*}{$\mathrm{CA}$} & 3 & 2,35 & 2,37 & 2,47 & 2,55 & 2,55 & 2,38 \\
\hline & 4 & 2,24 & 2,26 & 2,42 & 2,42 & 2,59 & 2,70 \\
\hline & 5 & 2,19 & 2,29 & 2,36 & 2,61 & 2,58 & 2,71 \\
\hline & Média & 2,31 & 2,34 & 2,44 & 2,52 & 2,50 & 2,54 \\
\hline
\end{tabular}

${ }^{a} \mathrm{GDP}=$ Ganho diário de peso, $\mathrm{CDR}=$ Consumo de ração e $\mathrm{CA}=$ Conversão alimentar. 
Tabela A2 . Desempenho de suínos na fase de terminação.

Variáveis $^{a} \quad$ Níveis de inclusão da levedura desidratada na ração, \%

\begin{tabular}{ccccccc}
\hline Bloco & 0,00 & 3,50 & 7,00 & 10,50 & 14,00 & 17,50 \\
\hline 1 & 1,087 & 1,153 & 1,120 & 0,974 & 1,009 & 1,023 \\
2 & 1,161 & 1,075 & 0,953 & 1,087 & 0,909 & 1,089
\end{tabular}

GDP,kg

$3 \quad 1,068 \quad 0,946 \quad 1,111 \quad 1,044 \quad 0,987 \quad 1,011$

$\begin{array}{lllllll}4 & 1,093 & 1,051 & 1,071 & 0,939 & 1,033 & 0,934\end{array}$

$\begin{array}{lllllll}5 & 1,063 & 1,014 & 1,146 & 1,023 & 1,013 & 1,018\end{array}$

\begin{tabular}{ccccccc}
\cline { 2 - 6 } Média & 1,094 & 1,048 & 1,080 & 1,013 & 0,990 & 1,015 \\
\hline 1 & 3,27 & 3,10 & 2,98 & 2,95 & 3,12 & 2,90 \\
2 & 3,44 & 3,16 & 2,56 & 3,32 & 2,76 & 3,45
\end{tabular}

$\begin{array}{llllllll}\mathrm{CDR}, \mathrm{kg} & 3 & 3,16 & 2,86 & 3,41 & 3,04 & 2,92 & 2,98\end{array}$

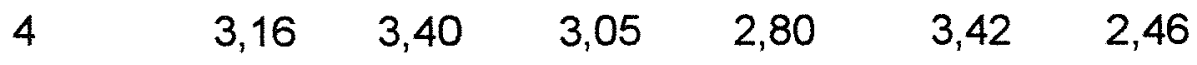

5

$2,92 \quad 2,86 \quad 3,21 \quad 2,98 \quad 3,11 \quad 2,85$

Média 3,1

\begin{tabular}{|c|c|c|c|c|c|c|c|}
\hline & 1 & 3,01 & 2,68 & 2,66 & 3,02 & 3,09 & 2,84 \\
\hline & 2 & 2,97 & 2,94 & 2,69 & 3,05 & 3,04 & 3,17 \\
\hline \multirow[t]{4}{*}{$\mathrm{CA}$} & 3 & 2,96 & 3,02 & 3,07 & 2,91 & 2,96 & 2,95 \\
\hline & 4 & 2,89 & 3,24 & 2,84 & 2,98 & 3,31 & 2,63 \\
\hline & 5 & 2,75 & 2,82 & 2,80 & 2,91 & 3,07 & 2,80 \\
\hline & Média & 2,91 & 2,94 & 2,81 & 2,98 & 3,10 & 2,88 \\
\hline
\end{tabular}

a $\mathrm{GDP}=$ Ganho diário de peso, $\mathrm{CDR}=$ Consumo diário de ração e $\mathrm{CA}=$ Conversão alimentar. 
Tabela A 3 . Desempenho de suínos no período total

Niveis de inclusão da levedura desidratada na ração, \%

$\begin{array}{llllllll}\text { Variáveis }^{\mathrm{a}} & \text { Bloco } & 0,00 & 3,50 & 7,00 & 10,50 & 14,00 & 17,50\end{array}$

\begin{tabular}{|c|c|c|c|c|c|c|c|}
\hline & 1 & 1,052 & 1,066 & 1,042 & 0,978 & 1,001 & 0,986 \\
\hline & 2 & 1,143 & 1,032 & 0,958 & 1,043 & 0,918 & 1,082 \\
\hline \multirow[t]{6}{*}{ GDP, $\mathrm{kg}$} & 3 & 1,029 & 0,946 & 1,062 & 1,005 & 0,976 & 0,987 \\
\hline & 4 & 1,053 & 1,017 & 1,054 & 0,957 & 0,984 & 0,889 \\
\hline & 5 & 0,992 & 0,986 & 1,064 & 1,011 & 0,959 & 0,945 \\
\hline & Média & 1,054 & 1,010 & 1,036 & 0,999 & 0,967 & 0,978 \\
\hline & 1 & 2,89 & 2,75 & 2,75 & 2,79 & 2,81 & 2,73 \\
\hline & 2 & 3,08 & 2,83 & 2,43 & 2,90 & 2,50 & 3,13 \\
\hline \multirow[t]{6}{*}{ CDR,kg } & 3 & 2,72 & 2,53 & 2,93 & 2,74 & 2,68 & 2,62 \\
\hline & 4 & 2,71 & 2,81 & 2,78 & 2,584 & 2,92 & 2,37 \\
\hline & 5 & 2,41 & 2,47 & 2,72 & 2,76 & 2,67 & 2,60 \\
\hline & Média & 2,76 & 2,68 & 2,72 & 2,75 & 2,72 & 2,69 \\
\hline & 1 & 2,74 & 2,52 & 2,64 & 2,85 & 2,80 & 2,63 \\
\hline & 2 & 2,70 & 2,74 & 2,54 & 2,78 & 2,72 & 2,89 \\
\hline \multirow[t]{4}{*}{$C A$} & 3 & 2,65 & 2,67 & 2,76 & 2,73 & 2,74 & 2,65 \\
\hline & 4 & 2,58 & 2,76 & 2,63 & 2,70 & 2,97 & 2,66 \\
\hline & 5 & 2,43 & 2,51 & 2,55 & 2,73 & 2,79 & 2,75 \\
\hline & Média & 2,62 & 2,64 & 2,63 & 2,76 & 2,81 & 2,72 \\
\hline
\end{tabular}

${ }^{a}$ GDP = Ganho diário de peso, $\mathrm{CDR}=$ Consumo de ração e CA = Conversão alimentar. 
Tabela A 4. Dados originais da avaliação de carcaça do bloco 1.

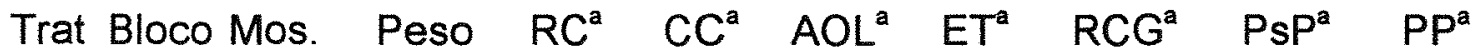
$(\mathrm{kg})(\%) \quad(\mathrm{cm})\left(\mathrm{cm}^{2}\right) \quad(\mathrm{cm})$

\begin{tabular}{llllllllllll}
\hline 1 & 1 & 158 & 77,10 & 77,82 & 92,50 & 33,60 & 2,65 & 0,42 & 11,20 & 36,48 \\
1 & 1 & 111 & 102,00 & 77,54 & 94,50 & 32,60 & 2,77 & 0,65 & 13,10 & 32,99 \\
2 & 1 & 99 & 91,30 & 76,88 & 93,00 & 31,60 & 2,93 & 0,61 & 12,70 & 35,77 \\
2 & 1 & 28 & 97,80 & 78,73 & 95,50 & 37,20 & 2,91 & 0,46 & 14,00 & 35,62 \\
3 & 1 & 14 & 87,80 & 78,70 & 93,00 & 42,70 & 2,65 & 0,31 & 12,50 & 35,61 \\
3 & 1 & 95 & 86,00 & 78,72 & 95,50 & 33,10 & 2,47 & 0,49 & 12,80 & 37,31 \\
3 & 1 & 117 & 97,30 & 77,18 & 91,50 & 35,30 & 3,33 & 0,61 & 13,10 & 34,38 \\
4 & 1 & 65 & 86,70 & 78,43 & 91,00 & 25,60 & 2,65 & 0,55 & 11,50 & 32,95 \\
4 & 1 & 210 & 84,30 & 79,83 & 95,50 & 35,90 & 2,32 & 0,35 & 12,10 & 35,17 \\
4 & 1 & 199 & 91,00 & 76,37 & 93,00 & 36,10 & 2,88 & 0,48 & 12,50 & 35,61 \\
5 & 1 & 200 & 90,00 & 80,44 & 92,50 & 28,10 & 3,47 & 0,68 & 12,50 & 34,15 \\
5 & 1 & 166 & 82,50 & 78,18 & 95,00 & 32,20 & 2,67 & 0,47 & 11,00 & 33,53 \\
5 & 1 & 194 & 96,60 & 78,05 & 94,00 & 37,40 & 3,03 & 0,44 & 13,50 & 34,35 \\
6 & 1 & 92 & 88,20 & 76,87 & 91,00 & 32,10 & 3,57 & 0,65 & 11,00 & 32,44
\end{tabular}

${ }^{a} \mathrm{RC}=$ Rendimento de Carcaça, $\mathrm{CC}=$ Comprimento de Carcaça, $\mathrm{AOL}=$ Área de Olho de Lombo, ET = Espessura de Toucinho, RGC = Relação Gordura Carne, PsP = Peso do Pernil, PP $=$ Percentagem de Pernil. 
Tabela A5. Dados originais da avaliação de carcaça do bloco 2.

Trat Mos. Bloc. Peso $\mathrm{RC}^{a} \quad \mathrm{CC}^{a} \mathrm{AOL}^{a} \quad \mathrm{ET}^{a} \quad \mathrm{RCG}^{\mathrm{a}} \quad \mathrm{PsP}^{\mathrm{a}} \mathrm{PP}^{\mathrm{a}}$

$\left(\begin{array}{lllll}(\mathrm{kg}) & (\%) & \mathrm{cm}) & \left(\mathrm{cm}^{2}\right) \quad(\mathrm{cm}) \quad(\mathrm{kg})\end{array}\right.$

(\%)

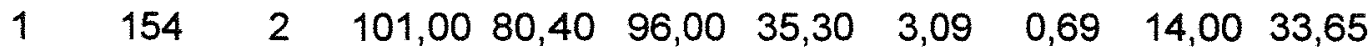

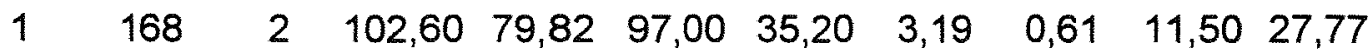

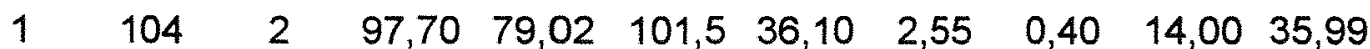

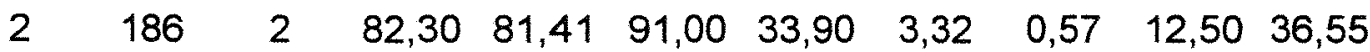

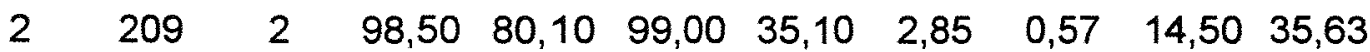

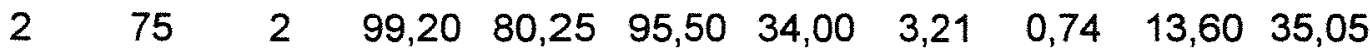

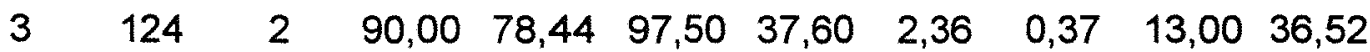

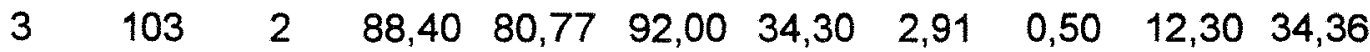

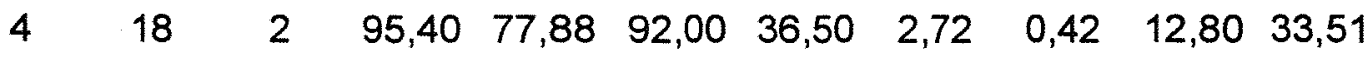

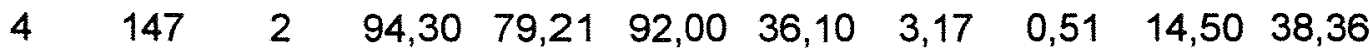

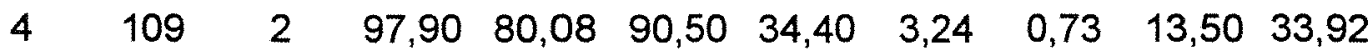

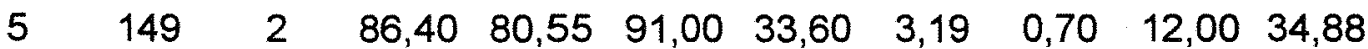

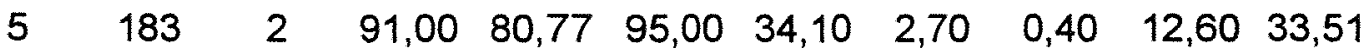

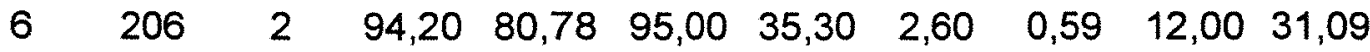

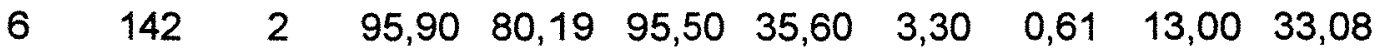

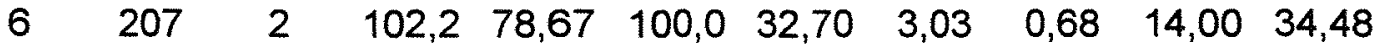

${ }^{\mathrm{a}} \mathrm{RC}=$ Rendimento de Carcaça, $\mathrm{CC}=$ Comprimento de Carcaça, $\mathrm{AOL}=$ Área de Olho de Lombo, ET = Espessura de Toucinho, RGC $=$ Relação Gordura Carne, PsP $=$ Peso do Pernil, $\mathrm{PP}=$ Percentagem de Pernil. 
Tabela A6. Dados originais da avaliação de carcaça do bloco 3.

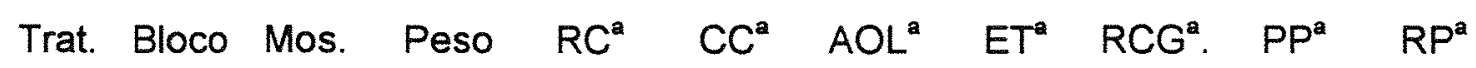
$(\mathrm{kg}) \quad(\%) \quad(\mathrm{cm}) \quad\left(\mathrm{cm}^{2}\right) \quad(\mathrm{cm}) \quad(\mathrm{kg})$

\begin{tabular}{|c|c|c|c|c|c|c|c|c|c|c|}
\hline 1 & 3 & 107 & 90,70 & 77,84 & 93,50 & 32,20 & 2,71 & 0,69 & 12,50 & 35,71 \\
\hline 1 & 3 & 16 & 97,70 & 81,68 & 95,00 & 38,30 & 3,19 & 0,52 & 14,30 & 35,66 \\
\hline 1 & 3 & 112 & 89,00 & 79,77 & 93,50 & 33,30 & 2,75 & 0,41 & 12,80 & 35,46 \\
\hline 2 & 3 & 149 & 94,40 & 79,87 & 93,00 & 30,50 & 3,51 & 0,83 & 13,60 & 35,98 \\
\hline 2 & 3 & 106 & 79,10 & 80,28 & 88,00 & 36,90 & 2,62 & 0,34 & 11,50 & 35,06 \\
\hline 2 & 3 & 168 & 86,90 & 81,59 & 93,00 & 34,10 & 3,72 & 0,68 & 13,50 & 38,46 \\
\hline 3 & 3 & 187 & 88,10 & 81,27 & 90,00 & 33,80 & 3,08 & 0,48 & 12,20 & 33,89 \\
\hline 3 & 3 & 70 & 99,40 & 80,68 & 99,00 & 41,70 & 3,00 & 0,48 & 15,50 & 37,99 \\
\hline 3 & 3 & 183 & 95,90 & 81,02 & 93,50 & 33,80 & 3,24 & 0,67 & 13,50 & 34,00 \\
\hline 4 & 3 & 203 & 91,10 & 78,05 & 101,00 & 36,70 & 2,16 & 0,40 & 13,40 & 37,85 \\
\hline 4 & 3 & 62 & 84,90 & 79,98 & 90,00 & 33,50 & 3,33 & 0,57 & 12,70 & 36,49 \\
\hline 4 & 3 & 116 & 98,70 & 78,22 & 94,00 & 34,00 & 2,74 & 0,54 & 14,50 & 36,90 \\
\hline 5 & 3 & 148 & 87,60 & 77,74 & 96,00 & 30,80 & 2,74 & 0,55 & 12,00 & 34,98 \\
\hline 5 & 3 & 200 & 90,20 & 80,93 & 95,50 & 35,10 & 3,36 & 0,61 & 12,50 & 33,33 \\
\hline 5 & 3 & 121 & 89,40 & 79,64 & 93,00 & 33,00 & 3,02 & 0,54 & 12,90 & 35,25 \\
\hline 6 & 3 & 188 & 91,00 & 80,44 & 89,50 & 33,40 & 3,17 & 0,60 & 13,50 & 36,00 \\
\hline 6 & 3 & 205 & 88,20 & 79,93 & 98,00 & 32,50 & 2,63 & 0,54 & 12,50 & 34,92 \\
\hline 6 & 3 & 118 & 89,60 & 79,35 & 94,00 & 33,30 & 2,68 & 0,49 & 11,60 & 32,22 \\
\hline
\end{tabular}
Lombo, ET = Espessura de Toucinho, RGC = Relação Gordura Came, PSP = Peso do Pernil, PP $=$ Percentagem de Pernil. 
Tabela A6. Dados originais da avaliação de carcaça do bloco 4.

Trat. Bloco Mos. Peso $\mathrm{RC}^{\mathrm{a}} \quad \mathrm{CC}^{\mathrm{a}} \mathrm{AOL}^{\mathrm{a}} \quad \mathrm{ET}^{2} \quad \mathrm{RCG}^{\mathrm{a}} \quad \mathrm{PsP}^{\mathrm{a}} \quad \mathrm{RP}^{\mathrm{a}}$

(kg) $\quad(\%) \quad(\mathrm{cm}) \quad\left(\mathrm{cm}^{2}\right) \quad(\mathrm{cm}) \quad(\mathrm{kg}) \quad(\%)$

\begin{tabular}{|c|c|c|c|c|c|c|c|c|c|c|}
\hline 1 & 4 & 137 & 93,40 & 78,37 & 94,50 & 31,90 & 2,43 & 0,45 & 13,00 & 35,13 \\
\hline 1 & 4 & 76 & 106,60 & 79,17 & 101,00 & 35,00 & 2,54 & 0,63 & 15,00 & 35,54 \\
\hline 2 & 4 & 108 & 109,90 & 79,10 & 95,00 & 33,70 & 3,29 & 0,63 & 14,00 & 34,23 \\
\hline 2 & 4 & 23 & 94,30 & 80,91 & 94,50 & 33,80 & 2,58 & 0,56 & 12,50 & 32,55 \\
\hline 3 & 4 & 208 & 93,90 & 79,34 & 99,00 & 36,50 & 2,79 & 0,37 & 13,00 & 34,39 \\
\hline 3 & 4 & 102 & 107,50 & 80,46 & 95,00 & 34,50 & 3,43 & 0,74 & 16,30 & 37,38 \\
\hline 4 & 4 & 220 & 93,80 & 80,17 & 95,50 & 29,37 & 2,85 & 0,44 & 12,50 & 32,89 \\
\hline 4 & 4 & 81 & 98,00 & 77,65 & 94,50 & 31,50 & 3,24 & 0,70 & 13,80 & 35,84 \\
\hline 5 & 4 & 133 & 94,00 & 79,36 & 94,50 & 38,20 & 2,81 & 0,46 & 13,60 & 35,79 \\
\hline 5 & 4 & 211 & 97,50 & 81,13 & 98,00 & 40,60 & 3,71 & 0,58 & 13,50 & 33,75 \\
\hline 6 & 4 & 188 & 94,90 & 79,98 & 94,50 & 33,20 & 2,93 & 0,56 & 14,60 & 37,43 \\
\hline 6 & 4 & 27 & 83,70 & 79,33 & 94,00 & 33,30 & 2,21 & 0,41 & 12,30 & 32,54 \\
\hline
\end{tabular}

${ }^{\mathrm{a}} \mathrm{RC}=$ Rendimento de Carcaça, $\mathrm{CC}=$ Comprimento de Carcaça, $\mathrm{AOL}=$ Área de Olho de Lombo, ET = Espessura de Toucinho, RGC = Relação Gordura Carne, PSP = Peso do Pernil, PP $=$ Percentagem de Pernil. 
Tabela A7. Dados originais da avaliação de carcaça do bloco 5.

Trat. Bloco Mos. Peso $\mathrm{RC}^{a} \quad \mathrm{CC}^{a} \mathrm{AOL}^{\mathrm{a}} \quad \mathrm{ET}^{\mathrm{a}} \quad \mathrm{RCG}^{\mathrm{a}} \mathrm{PSP}^{\mathrm{a}} \mathrm{PP}^{\mathrm{a}}$ $(\mathrm{kg})(\%) \quad(\mathrm{cm})\left(\mathrm{cm}^{2}\right) \quad(\mathrm{cm})$

$(\mathrm{kg}) \quad(\%)$

\begin{tabular}{|c|c|c|c|c|c|c|c|c|c|c|}
\hline 1 & 5 & 184 & 87,00 & 80,92 & 92,00 & 34,80 & 2,73 & 0,53 & 12,50 & 35,41 \\
\hline 1 & 5 & 201 & 96,10 & 79,29 & 95,00 & 36,80 & 3,17 & 0,60 & 13,80 & 36,32 \\
\hline 2 & 5 & 189 & 86,80 & 80,64 & 91,00 & 40,40 & 2,71 & 0,38 & 12,40 & 35,53 \\
\hline 2 & 5 & 192 & 99,40 & 79,98 & 95,50 & 33,60 & 2,69 & 0,52 & 14,50 & 35,71 \\
\hline 3 & 5 & 117 & 93,60 & 79,27 & 93,00 & 38,20 & 2,70 & 0,53 & 13,00 & 34,57 \\
\hline 3 & 5 & 94 & 104,40 & 78,45 & 97,00 & 36,80 & 3,33 & 0,54 & 14,60 & 34,93 \\
\hline 4 & 5 & 105 & 100,00 & 81,00 & 91,50 & 37,30 & 2,56 & 0,60 & 13,50 & 32,77 \\
\hline 4 & 5 & 150 & 93,10 & 78,84 & 93,00 & 35,90 & 2,58 & 0,51 & 14,30 & 38,34 \\
\hline 5 & 5 & 225 & 89,96 & 77,68 & 93,50 & 40,60 & 2,64 & 0,39 & 13,60 & 38,53 \\
\hline 5 & 5 & 80 & 96,90 & 80,08 & 97,50 & 34,60 & 2,59 & 0,62 & 13,50 & 34,70 \\
\hline 6 & 5 & 159 & 89,90 & 79,20 & 95,50 & 33,60 & 2,45 & 0,54 & 13,00 & 35,91 \\
\hline 6 & 5 & 221 & 88,10 & 81,38 & 94,00 & 40,10 & 2,59 & 0,42 & 14,00 & 38,46 \\
\hline
\end{tabular}

${ }^{\mathrm{a}} \mathrm{RC}=$ Rendimento de Carcaça, $\mathrm{CC}=$ Comprimento de Carcaça, $\mathrm{AOL}=$ Área de Olho de Lombo, ET = Espessura de Toucinho, RGC = Relação Gordura Carne, PSP $=$ Peso do Pernil, PP = Percentagem de Pernil. 